\title{
RESEARCH
}

\section{Using Hierarchical Similarity To Examine The Genetics of Behçet's Disease}

\author{
Samuel J Shenoi and Erich J Baker ${ }^{*}$
}

\footnotetext{
${ }^{*}$ Correspondence:

Erich_Baker@baylor.edu

Department of Computer Science,

Baylor University, One Bear Place,

Waco, TX, USA

Full list of author information is

available at the end of the article

${ }^{\dagger}$ Equal contributor
}

\begin{abstract}
Behçet's disease (BD) is a multisystem inflammatory disease that affects patients along the historic silk road. Thus far, the pathogenesis of the disease has proved elusive due to the complex genetic interactions and unknown environmental or viral triggering factors of the disease. In this paper, we seek to clarify the genetic factors of the disease while also uncovering other diseases of interest that present with a similar genotype as BD. To do this, we employ a convergent functional genomics approach by leveraging the hierarchical similarity tool available in Geneweaver. Through our analysis, we were able to ascertain 7 BD consensus genes and 16 autoimmune diseases with genetic overlap with BD. The results of our study will inform further research into the pathogenesis of Behçet's Disease.
\end{abstract}

Keywords: Behçet Syndrome; genomics; autoimmune disease

\section{Introduction}

Behçet's disease (BD) is a multi-system inflammatory disease [1]. It was first described by Hulusi Behçet as a disease demonstrating lesions of the mouth, the genitalia, and the eye [2]. The disease is thought to be triggered in genetically predisposed individuals by a combination of viral infection and environmental factors, but the exact mechanism of infection is unknown [3].

The genetics of BD are of particular interest. In virtually every studied population, the HLA-B51 gene has been the most closely associated risk factor for BD [4]. However, a sizable portion of BD patients present as HLA-B51 negative, and, conversely, the high prevalence of HLA-B51 in American Indian populations where $\mathrm{BD}$ is rare indicates the role of at least one other genetic loci as a factor of $\mathrm{BD}$ pathogenesis $[4,5]$. Some potential candidates to fill this role have been identified including ERAP1, TNF- $\alpha$, and IL-10 [6, 7, 8, 9, 10, 11, 12, 13]. The lack of a clear mechanism of $\mathrm{BD}$ pathogenesis and the genetic variation present in $\mathrm{BD}$ patients makes it difficult to separate true genetic factors of the disease from background genetic noise.

The classification of BD as an autoimmune disease and the discovery of isolated shared genetic factors between other autoimmune diseases and BD is intriguing. For instance, ERAP1 has been shown to be a susceptibility gene in BD, psoriasis, and ankylosing spondylitis. Likewise, IL-10 has been associated with multiple other autoimmune diseases, including rheumatoid arthritis, systemic sclerosis, Kawasaki disease, Sjogren's syndrome, Grave's disease, myasthenia gravis, psoriasis, autoimmune lymphoproliferative syndrome, and $\mathrm{BD}[10,12,14,15]$. The molecular and 
genetic overlap between autoimmune diseases presents as a significant area for research, as gaining a deeper understanding of the shared genetic pathways of autoimmune diseases can have important implications for diagnosis, treatments, and future research[16].

Addition research posits an intriguing approach towards solving these problems. In addiction research single genes rarely impact clinical phenotype, and hundreds of variants are needed to fully explain underlying genetics of the diseases. Convergent functional genomics (CFG) is leveraged to isolate important signals against this background. The premise of CFG is straight forward: the more lines of evidence for a gene, the higher it is prioritized as a gene of interest [16, 17]. This approach allows data from sources such as Genome Wide Association Studies (GWAS), gene expression studies, and animal models to be synthesized as evidence to ascertain the impact of genes on phenotype [17]. Even data from sources with limited sample size or lack of replication studies can be used as data points in the CFG approach since it is the collective evidence that together makes up the prioritization list.

To implement the CFG approach, we leverage the computational power of the Geneweaver Hierarchical Similarity (HiSIM) graph [18]. This tool creates a graph that is a hierarchical network of multiway geneset intersections. The resulting geneset interaction graph enables users to find genes connected to all populated subsets of an input set of gene lists (genesets) [19]. The tool takes advantage of a bipartite data structure in order to dynamically enumerate maximal bicliques arranged into hierarchical associations $[18,19]$. Nodes at the top of the graph have a limited number of genes but many genesets, while nodes at the bottom of the graph have many genes but fewer genesets as evidence.

In this work, we use the CFG approach to first find candidate genes of interest for BD and evaluate other autoimmune diseases for genetic overlap with BD.

\section{Methods}

\subsection{Data Collection}

Genes associated with BD were collected as genesets on Geneweaver [19]. Each geneset contained a record of BD associated genes from a single study or source. Sixteen $\mathrm{BD}$ genesets were collected overall. Eleven of the genesets originated from GWAS studies and were collected by searching the GWAS Catalog and publicly available curated genesets from Geneweaver [20,19]. The combined GWAS data came from a global population that included samples from Iranian, Japanese, Turkish, Korean, Spanish, Western European, Middle Eastern, and Han Chinese populations. $[21,22,23,24,25,26,27,28,29,24]$. One of the GWAS studies collected data regarding $\mathrm{BD}$ and a special type of $\mathrm{BD}$ that effects the GI tract, Intestinal BD (IBD) [24]. This data source was split into two genesets for purposes of this study. Another geneset was created from the NCBI gene2mesh tool and was included in the study[30]. The Online Mendelian Inheritance in Man (OMIM) database provided an additional geneset tagged "autoinflammatory, familial, Behçet's-like" [31]. Another geneset was created using information compiled in Malacards [32]. The last two genesets came from a BD review paper that consolidated genes of interest and a BD gene expression profile paper [8,33]. Finally, we noticed that one of the existing $\mathrm{BD}$ genesets on Geneweaver did not include all of the BD associated genes identified 
by the cited GWAS study. To compensate for this, we created a new geneset from the same GWAS study and added all of the BD associated genes identified by the study to the geneset [34]. The union of all 16 genesets was subsequently collected using the Boolean Algebra tool on Geneweaver and stored as another geneset [19].

Genesets for twenty-seven conditions were compiled in order to test BD 's relation to other autoimmune diseases. Disease genesets were created by using the Geneweaver Boolean Algebra tool on publicly available curated genesets [19]. Due to the large data size, only human genes were used for this run. The list of conditions and number of genes present in the genesets can be seen in Table 1.

\subsection{BD HiSIM Run}

To find the consensus genes of BD between all of the collected data sources, the Geneweaver HiSIM graph was run with the 16 BD genesets as input. The parameters used to run the HiSIM graph are reported in Table 2.

\subsection{Autoimmune HiSIM Run}

To determine the genetic overlap between $\mathrm{BD}$ and other autoimmune diseases. The HiSIM graph tool was run on 27 autoimmune disease genesets constructed using the Boolean Algebra tool and the BD Union geneset. The parameters used to run the HiSIM graph are in Table 2.

The data from the Autoimmune HiSIM run was then filtered to find relevant connections between BD and other autoimmune diseases. The resulting graphs were then plotted using the igraph python package [35] and the BoutrosLab.plotting.general $\mathrm{R}$ package [36, 37]

\subsection{Jaccard Geneset Analysis}

After conducting the HiSIM run, a Jaccard Geneset analysis was conducted on autoimmune diseases identified as presenting with a high BD similarity. This analysis determines whether the geneset overlap identified in the Autoimmune Disease Run was statistically significant. The Jaccard Geneset analysis was run using the Jaccard Similarity tool on Geneweaver [19].

\subsection{Neighbor Joining Analysis}

In order to find the top five most genetically similar diseases to $\mathrm{BD}$, a neighbor joining tree was created using the ape $\mathrm{R}$ package [38]. The distance between any two diseases was defined using the normalized Jaccard formula seen in Formula 1.

$$
1-\frac{A \cap B}{\min (\operatorname{size}(A), \operatorname{size}(B))}
$$

The formula took into account the differences in set size between the two sets in order to determine their overlap. By taking the size of the intersection between the two sets and dividing it by the largest possible overlap that could occur between the two sets, the formula allowed sets of different sizes to be compared. The distance between all possible pair combinations of the 16 genes was calculated and stored in a distance matrix. The distance matrix was then used as input to the neighbor joining program from the ape $\mathrm{R}$ package[38, 36]. 


\section{Results}

\subsection{BD HiSIM Run}

Running the HiSIM graph on the BD collected genesets resulted in the graph shown in Figure 1. Genes found in more than 3 genesets are displayed in Table 3. HLA-B was identified in 7 genesets making it the most common gene amongst all tested genes. IL-10 was the next most common gene and was found in 6 genesets. IL23R was the third most common gene, found in 5 genesets. Finally, HLA-A, STAT4, MICA, and ERAP1 were all found in 4 genesets.

\subsection{Autoimmune Disease Run}

After collecting autoimmune genesets on Geneweaver, the HiSIM graph was run on 27 unique autoimmune diseases and BD. Figure 2 displays the results of this run. In Figure 2A, all edges between computed nodes are included. The resulting dataset was subsequently filtered in order to remove all nodes that are unrelated to BD; Figure 2B displays the results of filtering.

Figure 3 displays the genetic overlap between the autoimmune diseases and BD as determined by the HiSIM graph. Out of the 27 conditions tested, only 16 were found to have some genetic overlap with BD. The 16 identified candidates were then used to subsequently preform the Jaccard Analysis.

\subsection{Jaccard Geneset Analysis}

Using the 16 identified conditions from the Autoimmune HiSIM run, a Jaccard Geneset Analysis was run. The results from the Jaccard Geneset analysis found that the overlap between all of the conditions and BD did not reach a level of statistical significance(Figure 4).

\subsection{Neighbor Joining Analysis}

The genetic overlap between BD and the 16 identified autoimmune diseases was then normalized using Formula 1. The normalized genetic overlap was then used as input for the Neighbor Joining Tree, the results of which can be seen in Figure 5. The tree indicates that BD is closest to Sarcoidosis, Uveitis, Sjogren's Syndrome, Hemolytic Anemia, and Myositis.

\section{Discussion}

The results of the BD HiSIM graph run are consistent with previous BD research. All top scoring genes have previously been identified as having an association with BD $[39,8,10]$. The emergence of HLA-B as the top scoring gene is unsurprising given the history of HLA-B51 as a susceptibility gene of BD and its reputation as the primary gene of interest in $\mathrm{BD}[4,6,39]$.

The results of the $\mathrm{BD}$ autoimmune disease run identified 16 diseases with at least some genetic overlap with BD. While these associations were unable to achieve statistical significance based on the results of our Jaccard Similarity run (Figure 4), we believe that these results can be potentially attributed to the limitations of the Jaccard Similarity test. It has been documented that the Jaccard coefficient, which is used to calculate the Jaccard Similarity, is strongly affected by dataset size [40]. This represents a limitation to our current study that can be addressed in future work. 
Additional limitations to our study are primarily centered around data collection. Due to the limited genomics literature available for Behçet's Disease we were only able to collect 16 unique genesets for analysis. While sufficient for our current study, the addition of future GWAS and other genomic studies will help further elucidate the complex genomic interactions at play in BD. Similarly, our autoimmune disease HiSIM run, while large, is not exhaustive. All of the conditions collected were relatively common and data for these runs were limited to publicly available genesets already present in Geneweaver. This selection criteria excluded non-autoimmune conditions, such as cervical cancer, oral cavity cancer, and oropharyngeal cancer, that might mimic BD phenotype presentations.

To circumvent these limitations, we proposed a modified Jaccard similarity formula (Formula 1) to determine the genetic similarity between any two diseases. We then used this formula to construct a neighbor joining tree which allowed us to identify how genetically similar each of the 16 identified diseases were to BD.

The results of our CFG approach have the benefit of identifying autoimmune diseases with a shared genetic architecture, and is a promising strategy for identifying genes associated with BD. The inclusion of certain diseases in 16 identified diseases was expected. Most notably, Uveitis's high genetic overlap with BD was expected given that this condition is a symptom of BD [6]. Sjogren's Syndrome's inclusion in our list was expected as well given that Sjogren's Syndrome often presents with other autoimmune diseases [41, 42]. Because of the multiple reports of Sjogren's Syndrome and BD, Sjogren's Syndromes association with BD has already been tested and no association between the two was found [43, 42].

Of interest was the close proximity of Sarcoidosis and BD in the neighbor joining tree (Figure 5). Historically, there have been very few reports of patients presenting with both BD and Sarcoidosis [44, 45], but there has been a recent uptick in BD patients presenting with both Sarcoidosis and BD after treatment with TNF antagonists [44]. Clinically, it can be difficult to distinguish between BD and Sarcoidosis considering the similarity of the articular, neurological, and skin lesions between the two diseases [45].

Additionally, the inclusion of psoriasis in our list was noteworthy as well. Psoriatic arthritis has been documented to sometimes be confused with BD articular involvement [46]. Hahn et al. recently found that psoriasis patients were twice as likely to be diagnosed with BD based on an analysis of patient data from the National Health Insurance Database of Korea [47]. Finally, Intestinal BD is sometimes misdiagnosed as Crohn's Disease and vice versa due to the similarity of symptoms, so its inclusion in our list of related diseases was unsurprising[48].

These findings, coupled with our genetic analysis, might provide evidence for a related underlying genetic mechanism related to the pathogenesis of these diseases. It will be left up to future work to fully clarify these relationships.

There have been documented case reports of patients presenting with both BD and one of the other diseases identified from our analysis. There have been a handful of cases of patients presenting with both BD and Sclerosis [49, 50], Myositis [51, 52, 53, 54], Endometriosis [55], Graves' disease [56], Vitiligo [57, 58], Hemolytic Anemia [59], tuberculous thyroiditis [60, 61], and Biliary Liver Cirrhosis [62]. However, the inclusion of Alopecia Areata in this set of conditions was surprising. To 
bioRxiv preprint doi: https://doi.org/10.1101/2021.04.06.438717; this version posted April 15, 2021. The copyright holder for this preprint (which

was not certified by peer review) is the author/funder, who has granted bioRxiv a license to display the preprint in perpetuity. It is made

our knowledge, there have been no reported cases of patients presenting with both Alopecia Areata and BD nor evidence of an association between BD and Alopecia Areata.

\section{Conclusion}

Behçet's disease is a complex multi-system inflammatory disease in which the exact pathogenesis continues to elude researchers $[3,1]$. Genetically, the identification of HLA-B51 as a major, but not sole, susceptibility gene has led to the hunt for other genetic factors of the disease [4]. The resulting identification of multiple genes of interest, however, does not explicitly establish the contributions of each of these genes towards the overall presentation of the disease $[6,7,8,9,10,11,12,13]$. Furthermore, research into these genes has uncovered roles of these genes in the progression of other autoimmune diseases $[10,12,14,15]$. It is imperative to research autoimmune diseases in relation to other autoimmune diseases in order to fully understand human disease.

In this study, we employed a functional convergent genomics approach to discover 1) the genetic factors and 2) related autoimmune conditions of Behçet's Disease. The power of this approach lies in its ability to synthesize information from multiple genomics data sources [16] and in its recognition of shared genetic factors of autoimmune diseases $[10,11,12]$. The ability to quickly and accurately synthesize this information using the Geneweaver HiSIM graph presents a valuable opportunity for further discovery in this line of research [18]. Furthermore, our results using this approach confirmed existing BD research regarding the genetic factors of the disease and identified 16 autoimmune diseases that share an underlying genetic relationship to BD. Almost all of these associations - the only exception being Alopecia Areata - have documented clinical findings linking them with $\mathrm{BD}$, further providing evidence towards our results. It will be left up to further research to fully uncover the complex genetic interactions underlying these diseases as well as the shared genetic mechanisms between them.

Competing interests

The authors declare that they have no competing interests.

Author's contributions

S.S carried out the experiments and wrote the manuscript. E.B. supervised the project.

Acknowledgements

We thank our colleagues from Baylor University who provided insight and expertise that greatly assisted the research, although they may not agree with all of the interpretations/conclusions of this paper.

References

1. Davatchi F. Behcet's disease. International Journal of Rheumatic Diseases. 2014 May;17(4):355-357. Available from: http://doi.wiley.com/10.1111/1756-185X.12378.

2. Behçet H, Matteson EL. On relapsing, aphthous ulcers of the mouth, eye and genitalia caused by a virus. 1937. Clinical and Experimental Rheumatology. 2010 Aug;28(4 Suppl 60):S2-5.

3. Bulur I, Onder M. Behçet disease: New aspects. Clinics in Dermatology. 2017 Oct;35(5):421-434.

4. Verity DH, Marr JE, Ohno S, Wallace GR, Stanford MR. Behçet's disease, the Silk Road and HLA-B51: historical and geographical perspectives: Behçet's disease, the Silk Road and HLA-B51. Tissue Antigens. 1999 Sep;54(3):213-220. Available from: http://doi.wiley.com/10.1034/j.1399-0039.1999.540301.x.

5. Muruganandam M, Rolle NA, Sibbitt WL Jr, Cook GB, Emil NS, Fangtham M, et al. Characteristics of Behcet's Disease in the American Southwest. Seminars in Arthritis and Rheumatism. 2019 Oct;49(2):296-302. Available from: https://linkinghub.elsevier.com/retrieve/pii/S0049017218307911.

6. Salmaninejad A, Gowhari A, Hosseini S, Aslani S, Yousefi M, Bahrami T, et al. Genetics and immunodysfunction underlying Behçet's disease and immunomodulant treatment approaches. Journal of Immunotoxicology. 2017;14(1):137-151. 
bioRxiv preprint doi: https://doi.org/10.1101/2021.04.06.438717; this version posted April 15, 2021. The copyright holder for this preprint (which was not certified by peer review) is the author/funder, who has granted bioRxiv a license to display the preprint in perpetuity. It is made available under aCC-BY-NC-ND 4.0 International license.

7. Piga M, Mathieu A. Genetic susceptibility to Behcet's disease: role of genes belonging to the MHC region. Rheumatology. 2011 Feb;50(2):299-310. Available from: https://academic.oup.com/rheumatology/article-lookup/doi/10.1093/rheumatology/keq331.

8. Deng Y, Zhu W, Zhou X. Immune Regulatory Genes Are Major Genetic Factors to Behcet Disease: Systematic Review. The Open Rheumatology Journal. 2018 Jun;12(1):70-85. Available from: https://openrheumatologyjournal.com/VOLUME/12/PAGE/70/.

9. Leccese P, Alpsoy E. Behçet's Disease: An Overview of Etiopathogenesis. Frontiers in Immunology. 2019;10:1067.

10. Kirino Y, Nakajima H. Clinical and Genetic Aspects of Behçet's Disease in Japan. Internal Medicine. 2019 May;58(9):1199-1207. Available from: https://www.jstage.jst.go.jp/article/internalmedicine/58/9/58 $035-18 /$ a rticle

11. Takeuchi M, Ombrello MJ, Kirino Y, Erer B, Tugal-Tutkun I, Seyahi E, et al. A single endoplasmic reticulum aminopeptidase- 1 protein allotype is a strong risk factor for Behçet's disease in HLA-B*51 carriers. Annals of the Rheumatic Diseases. 2016 Dec;75(12):2208-2211. Available from: http://ard.bmj.com/lookup/doi/10.1136/annrheumdis-2015-209059.

12. Conde-Jaldón M, Montes-Cano MA, García-Lozano JR, Ortiz-Fernández L, Ortego-Centeno N, González-León $\mathrm{R}$, et al. Epistatic Interaction of ERAP1 and HLA-B in Behçet Disease: A Replication Study in the Spanish Population. PLoS ONE. 2014 Jul;9(7):e102100. Available from: https://dx.plos.org/10.1371/journal.pone.0102100.

13. Sousa I, Shahram F, Francisco D, Davatchi F, Abdollahi BS, Ghaderibarmi F, et al. Brief Report: Association of CCR1, KLRC4, IL12A-AS1, STAT4, and ERAP1 With Behçet's Disease in Iranians. Arthritis \& Rheumatology. 2015;67(10):2742-2748. Available from: https://onlinelibrary.wiley.com/doi/abs/10.1002/art.39240.

14. Tran TM, Colbert RA. Endoplasmic reticulum aminopeptidase 1 and rheumatic disease: functional variation. Current Opinion in Rheumatology. $2015 \mathrm{Jul} ; 27(4): 357-363$. Available from: http://content.wkhealth.com/linkback/openurl?sid=WKPTLP:landingpagean=00002281-201507000-00007

15. Gibson AW, Edberg JC, Wu J, Kimberly RP. The Role of IL-10 in Autoimmune Pathology. Landes Bioscience; 2013. Publication Title: Madame Curie Bioscience Database [Internet]. Available from: https://www.ncbi.nlm.nih.gov/books/NBK6234/.

16. Spanagel R. Convergent functional genomics in addiction research - a translational approach to study candidate genes and gene networks. In Silico Pharmacology. 2013;1:18.

17. Niculescu AB. Convergent functional genomics of psychiatric disorders. American Journal of Medical Genetics Part B: Neuropsychiatric Genetics. 2013 Oct;162(7):587-594. Available from: https://onlinelibrary.wiley.com/doi/10.1002/ajmg.b.32163.

18. Baker E, Bubier JA, Reynolds T, Langston MA, Chesler EJ. GeneWeaver: data driven alignment of cross-species genomics in biology and disease. Nucleic Acids Research. 2016 Jan;44(D1):D555-D559. Available from: https://academic.oup.com/nar/article-lookup/doi/10.1093/nar/gkv1329.

19. Baker EJ, Jay JJ, Bubier JA, Langston MA, Chesler EJ. GeneWeaver: a web-based system for integrative functional genomics. Nucleic Acids Research. 2012 Jan;40(Database issue):D1067-1076.

20. MacArthur J, Bowler E, Cerezo M, Gil L, Hall P, Hastings E, et al. The new NHGRI-EBI Catalog of published genome-wide association studies (GWAS Catalog). Nucleic Acids Research. 2017 Jan;45(D1):D896-D901. Available from: https://academic.oup.com/nar/article-lookup/doi/10.1093/nar/gkw1133.

21. Lee YJ, Horie Y, Wallace GR, Choi YS, Park JA, Choi JY, et al. Genome-wide association study identifies GIMAP as a novel susceptibility locus for Behçet's disease. Annals of the Rheumatic Diseases. 2013 Sep;72(9):1510-1516. Available from: http://ard.bmj.com/lookup/doi/10.1136/annrheumdis-2011-200288.

22. Fei Y, Webb R, Cobb BL, Direskeneli H, Saruhan-Direskeneli G, Sawalha AH. Identification of novel genetic susceptibility loci for Behçet's disease using a genome-wide association study. Arthritis Research \& Therapy. 2009;11(3):R66.

23. Ortiz-Fernández L, Carmona FD, Montes-Cano MA, García-Lozano JR, Conde-Jaldón M, Ortego-Centeno N, et al. Genetic Analysis with the Immunochip Platform in Behçet Disease. Identification of Residues Associated in the HLA Class I Region and New Susceptibility Loci. PloS One. 2016;11(8):e0161305.

24. Kim SW, Jung YS, Ahn JB, Shin ES, Jang HW, Lee HJ, et al. Identification of genetic susceptibility loci for intestinal Behçet's disease. Scientific Reports. 2017;7:39850.

25. Mizuki N, Meguro A, Ota M, Ohno S, Shiota T, Kawagoe T, et al. Genome-wide association studies identify IL23R-IL12RB2 and IL10 as Behçet's disease susceptibility loci. Nature Genetics. 2010 Aug;42(8):703-706.

26. Kirino Y, Bertsias G, Ishigatsubo Y, Mizuki N, Tugal-Tutkun I, Seyahi E, et al. Genome-wide association analysis identifies new susceptibility loci for Behçet's disease and epistasis between HLA-B*51 and ERAP1. Nature Genetics. 2013 Feb;45(2):202-207.

27. Xavier JM, Shahram F, Sousa I, Davatchi F, Matos M, Abdollahi BS, et al. FUT2 : filling the gap between genes and environment in Behçet's disease? Annals of the Rheumatic Diseases. 2015 Mar;74(3):618-624. Available from: http://ard.bmj.com/lookup/doi/10.1136/annrheumdis-2013-204475.

28. Hou S, Yang Z, Du L, Jiang Z, Shu Q, Chen Y, et al. Identification of a susceptibility locus in STAT4 for Behçet's disease in Han Chinese in a genome-wide association study. Arthritis \& Rheumatism. 2012;64(12):4104-4113. Available from: https://onlinelibrary.wiley.com/doi/abs/10.1002/art.37708.

29. Kappen JH, Medina-Gomez C, van Hagen PM, Stolk L, Estrada K, Rivadeneira F, et al. Genome-wide association study in an admixed case series reveals IL12A as a new candidate in Behçet disease. PloS One. 2015;10(3):e0119085

30. Athey BD, Cavalcoli JD, Jagadish HV, Omenn GS, Mirel B, Kretzler M, et al. The NIH National Center for Integrative Biomedical Informatics (NCIBI). Journal of the American Medical Informatics Association. 2012 Mar;19(2):166-170. Available from: https://academic.oup.com/jamia/article-lookup/doi/10.1136/amiajnl-2011-000552.

31. Amberger JS, Bocchini CA, Scott AF, Hamosh A. OMIM.org: leveraging knowledge across phenotype-gene 
bioRxiv preprint doi: https://doi.org/10.1101/2021.04.06.438717; this version posted April 15, 2021. The copyright holder for this preprint (which was not certified by peer review) is the author/funder, who has granted bioRxiv a license to display the preprint in perpetuity. It is made available under aCC-BY-NC-ND 4.0 International license.

relationships. Nucleic Acids Research. 2019 Jan;47(D1):D1038-D1043. Available from: https://academic.oup.com/nar/article/47/D1/D1038/5184722.

32. Rappaport N, Nativ N, Stelzer G, Twik M, Guan-Golan Y, Iny Stein T, et al. MalaCards: an integrated compendium for diseases and their annotation. Database. 2013 Jan;2013. Available from: https://academic.oup.com/database/article/doi/10.1093/database/bat018/331798.

33. Puccetti A, Fiore PF, Pelosi A, Tinazzi E, Patuzzo G, Argentino G, et al. Gene Expression Profiling in Behcet's Disease Indicates an Autoimmune Component in the Pathogenesis of the Disease and Opens New Avenues for Targeted Therapy. Journal of Immunology Research. 2018;2018:1-18. Available from: https://www.hindawi.com/journals/jir/2018/4246965/.

34. Remmers EF, Cosan F, Kirino Y, Ombrello MJ, Abaci N, Satorius C, et al. Genome-wide association study identifies variants in the MHC class I, IL10, and IL23R-IL12RB2 regions associated with Behçet's disease. Nature Genetics. 2010 Aug;42(8):698-702.

35. Gabor Csardi, Tamas Nepusz. The igraph software package for complex network research. InterJournal. 2006; Complex Systems:1695. Available from: http://igraph.org.

36. R Core Team. R: A Language and Environment for Statistical Computing. Vienna, Austria: R Foundation for Statistical Computing; 2013. Available from: http://www.R-project.org/.

37. Paul Boutros. BoutrosLab.plotting.general: Functions to Create Publication-Quality Plots; 2020. R package version 6.0.1. Available from: https://CRAN.R-project.org/package=BoutrosLab. plotting.general.

38. E Paradis, K Schliep. ape 5.0: an environment for modern phylogenetics and evolutionary analyses in $\{R\}$. Bioinformatics. 2019:35:526-528

39. Mizuki N, Inoko H, Ohno S. Molecular genetics (HLA) of Behçet's disease. Yonsei Medical Journal. 1997 Dec;38(6):333-349.

40. Salvatore S, Dagestad Rand K, Grytten I, Ferkingstad E, Domanska D, Holden L, et al. Beware the Jaccard: the choice of similarity measure is important and non-trivial in genomic colocalisation analysis. Briefings in Bioinformatics. 2020 Sep;21(5):1523-1530. Available from: https://academic.oup.com/bib/article/21/5/1523/5586919.

41. Nair J, Singh T. Sjogren's syndrome: Review of the aetiology, Pathophysiology a Potential therapeutic interventions. Journal of Clinical and Experimental Dentistry. 2017;p. 0-0. Available from: http://www.medicinaoral.com/medoralfree01/aop/53605.pdf.

42. Günaydin I, Ustündağ C, Kaner G, Pazarli H, Yurdakul S, Hamuryudan V, et al. The prevalence of Sjögren's syndrome in Behçet's syndrome. The Journal of Rheumatology. 1994 Sep;21(9):1662-1664.

43. Ju FH, Xu TZ, Hong HH, Mao H, Wang M, Wang Z. Behcet disease combined with Sjogren syndrome: A unique case report and literature review. Medicine. 2018 Mar;97(12):e0138.

44. Louro M, Vaio T, Crespo J, Santos R, Carvalho A. Pulmonary Sarcoidosis in Behçet's Disease Treated with Adalimumab. European Journal of Case Reports in Internal Medicine. 2017;4(4):000576.

45. Berriche O, Hammami S, Cherif Y, Younes S, Alaya W, Sfar M. Behçet's disease and sarcoidosis: a rare association. Research. 2014 Jun;1. Available from: http://www.labome.org/research/Beh-et-s-disease-and-sarcoidosis-a-rare-association.html.

46. Kokturk A. Clinical and Pathological Manifestations with Differential Diagnosis in Behçet's Disease. Pathology Research International. 2012 Nov;2012:1-9. Available from: https://www.hindawi.com/journals/pri/2012/690390/.

47. Hahn HJ, Kwak SG, Kim DK, Kim JY. Association of Behçet disease with psoriasis and psoriatic arthritis. Scientific Reports. 2021 Dec;11(1):2531. Available from: http://www.nature.com/articles/s41598-021-81972-4.

48. Nordstrom E, Fischer M. The great masquerader: Behcet's disease. Case Reports. 2014 Apr;2014(apr19 1):bcr2013202919-bcr2013202919. Available from: https://casereports.bmj.com/lookup/doi/10.1136/bcr-2013-202919.

49. Watanabe H, Yashiro M, Asano T, Sato S, Takahashi A, Katakura K, et al. A CASE OF BEHCET'S DISEASE AND SYSTEMIC SCLEROSIS DEVELOPING AFTER AN EARTHQUAKE DISASTER FUKUSHIMA JOURNAL OF MEDICAL SCIENCE. 2015;61(1):86-90. Available from: https://www.jstage.jst.go.jp/article/fms/61/1/61 $2014-27 /$ article.

50. Ichimura Y, Asano Y, Takahashi T, Toyama T, Taniguchi T, Tamaki Z, et al. Development of systemic sclerosis in patients with Behçet's disease: Remission of Behçet's disease in parallel with the progression of skin sclerosis. The Journal of Dermatology. 2014 Dec;41(12):1113-1114. Available from: http://doi.wiley.com/10.1111/1346-8138.12688.

51. Ogose T, Tamaki W, Shinahara K, Kaneko M, Wakata Y, Naruse K. A case of recurrent myositis as the main manifestation of Behçet disease. Pediatrics International. 2010 Apr;52(2):e101-e104. Available from: http://doi.wiley.com/10.1111/j.1442-200X.2010.03082.x.

52. Dursun D, Akova $Y$, Yücel E. Myositis and scleritis associated with Behcet's disease: an atypical presentation. Ocular Immunology and Inflammation. 2004 Dec;12(4):329-332.

53. Sarui $\mathrm{H}$. Necrotising myositis in Behcet's disease: characteristic features on magnetic resonance imaging and a review of the literature. Annals of the Rheumatic Diseases. 2002 Aug;61(8):751-752. Available from: https://ard.bmj.com/lookup/doi/10.1136/ard.61.8.751

54. Carlos Arteaga R, Otto J Hernandez F, Renato Puppi M, Olga Judith Hernández F. Polymyositis in Adamantiades-Behçet's Disease. International Journal of Neurology and Neurotherapy. 2020 Jan;7(1) Available from: https://www.clinmedjournals.org/articles/ijnn/international-journal-of-neurology-andneurotherapy-ijnn-7-094.php?jid=ijnn

55. Mignemi G, Facchini C, Raimondo D, Montanari G, Ferrini G, Seracchioli R. A Case Report of Nasal Endometriosis in a Patient Affected by Behcet's Disease. Journal of Minimally Invasive Gynecology. 2012 Jul;19(4):514-516. Available from: https://linkinghub.elsevier.com/retrieve/pii/S1553465012001082.

56. Joshi H, Shahriar I, Sharma P, Sagi SV, Oyibo SO. A rare coexistence of Behcet's disease and Graves' thyrotoxicosis in a young man: a case report. Oxford Medical Case Reports. 2020 Jan;2020(1):omz132. 
bioRxiv preprint doi: https://doi.org/10.1101/2021.04.06.438717; this version posted April 15, 2021. The copyright holder for this preprint (which was not certified by peer review) is the author/funder, who has granted bioRxiv a license to display the preprint in perpetuity. It is made available under aCC-BY-NC-ND 4.0 International license.

Available from: https://academic.oup.com/omcr/article/doi/10.1093/omcr/omz132/5669843.

57. Ertaș R, Özyurt K, Avcı A, Ketenci Ertas S, Atasoy M. Case Report: Behçet's disease accompanied with vitiligo. F1000Research. 2017 Mar;6:310. Available from: https://f1000research.com/articles/6-310/v1.

58. Guney E, Akcali G, Akcay BI, Unlu C, Erdogan G, Bozkurt TK, et al. Vitiligo in a Patient Treated with Interferon Alpha-2a for Behçet's Disease. Case Reports in Medicine. 2012;2012:1-3. Available from: http://www.hindawi.com/journals/crim/2012/387140/.

59. Chyuma Y, Utsunomiya A, Saito T, Hanada S, Nishimata H, Arima T. [Hemolytic anemia complicated with Behçet's disease and myelodysplastic syndrome]. [Rinsho Ketsueki] The Japanese Journal of Clinical Hematology. 1992 Mar;33(3):333-337.

60. Chung SY, Oh KK, Chang HS. Sonographic findings of tuberculous thyroiditis in a patient with Behçet's syndrome: Tuberculous Thyroiditis. Journal of Clinical Ultrasound. 2002 Mar;30(3):184-188. Available from: http://doi.wiley.com/10.1002/jcu.10041.

61. Carvalho FP, Maia B, Marinho A, Veloso A, Cunha I, Leite I, et al. Subacute thyroiditis in association with psoriasis and behcet's disease. Endocrine Abstracts. 2018 May;Available from: http://www.endocrine-abstracts.org/ea/0056/ea0056p635.htm.

62. Iwadate $\mathrm{H}$. A case of primary biliary cirrhosis complicated by Behçet's disease and palmoplantar pustulosis. World Journal of Gastroenterology. 2006;12(13):2136. Available from: http://www.wjgnet.com/1007-9327/full/v12/i13/2136.htm.

63. Köhler S, Doelken SC, Mungall CJ, Bauer S, Firth HV, Bailleul-Forestier I, et al. The Human Phenotype Ontology project: linking molecular biology and disease through phenotype data. Nucleic Acids Research. 2014 Jan;42(Database issue):D966-974.

64. Birlea SA, Gowan K, Fain PR, Spritz RA. Genome-wide association study of generalized vitiligo in an isolated European founder population identifies SMOC2, in close proximity to IDDM8. The Journal of Investigative Dermatology. 2010 Mar;130(3):798-803.

65. Cheong KA, Kim NH, Noh M, Lee AY. Three new single nucleotide polymorphisms identified by a genome-wide association study in Korean patients with vitiligo. Journal of Korean Medical Science. 2013 May;28(5):775-779.

66. Jin Y, Birlea SA, Fain PR, Gowan K, Riccardi SL, Holland PJ, et al. Genome-wide analysis identifies a quantitative trait locus in the MHC class II region associated with generalized vitiligo age of onset. The Journal of Investigative Dermatology. 2011 Jun;131(6):1308-1312.

67. Jin Y, Birlea SA, Fain PR, Ferrara TM, Ben S, Riccardi SL, et al. Genome-wide association analyses identify 13 new susceptibility loci for generalized vitiligo. Nature Genetics. 2012 May;44(6):676-680.

68. Jin Y, Birlea SA, Fain PR, Gowan K, Riccardi SL, Holland PJ, et al. Variant of TYR and autoimmunity susceptibility loci in generalized vitiligo. The New England Journal of Medicine. 2010 May;362(18):1686-1697.

69. Quan C, Ren YQ, Xiang LH, Sun LD, Xu AE, Gao XH, et al. Genome-wide association study for vitiligo identifies susceptibility loci at 6q27 and the MHC. Nature Genetics. 2010 Jul;42(7):614-618.

70. Tang XF, Zhang Z, Hu DY, Xu AE, Zhou HS, Sun LD, et al. Association analyses identify three susceptibility Loci for vitiligo in the Chinese Han population. The Journal of Investigative Dermatology. 2013 Feb;133(2):403-410.

71. Bracken S, Byrne G, Kelly J, Jackson J, Feighery C. Altered gene expression in highly purified enterocytes from patients with active coeliac disease. BMC genomics. 2008 Aug;9:377.

72. Carr EJ, Niederer HA, Williams J, Harper L, Watts RA, Lyons PA, et al. Confirmation of the genetic association of CTLA4 and PTPN22 with ANCA-associated vasculitis. BMC medical genetics. 2009 Dec;10:121.

73. Curley CR, Monsuur AJ, Wapenaar MC, Rioux JD, Wijmenga C. A functional candidate screen for coeliac disease genes. European journal of human genetics: EJHG. 2006 Nov;14(11):1215-1222.

74. Diosdado B, Wapenaar MC, Franke L, Duran KJ, Goerres MJ, Hadithi M, et al. A microarray screen for novel candidate genes in coeliac disease pathogenesis. Gut. 2004 Jul;53(7):944-951.

75. Dubois PCA, Trynka G, Franke L, Hunt KA, Romanos J, Curtotti A, et al. Multiple common variants for celiac disease influencing immune gene expression. Nature Genetics. 2010 Apr;42(4):295-302.

76. Festen EAM, Goyette P, Green T, Boucher G, Beauchamp C, Trynka G, et al. A meta-analysis of genome-wide association scans identifies IL18RAP, PTPN2, TAGAP, and PUS10 as shared risk loci for Crohn's disease and celiac disease. PLoS genetics. 2011 Jan;7(1):e1001283.

77. Garner C, Ahn R, Ding YC, Steele L, Stoven S, Green PH, et al. Genome-wide association study of celiac disease in North America confirms FRMD4B as new celiac locus. PloS One. 2014;9(7):e101428.

78. Hunt KA, Zhernakova A, Turner G, Heap GAR, Franke L, Bruinenberg M, et al. Newly identified genetic risk variants for celiac disease related to the immune response. Nature Genetics. 2008 Apr;40(4):395-402.

79. Li YR, Li J, Zhao SD, Bradfield JP, Mentch FD, Maggadottir SM, et al. Meta-analysis of shared genetic architecture across ten pediatric autoimmune diseases. Nature Medicine. 2015 Sep;21(9):1018-1027.

80. Östensson M, Montén C, Bacelis J, Gudjonsdottir AH, Adamovic S, Ek J, et al. A possible mechanism behind autoimmune disorders discovered by genome-wide linkage and association analysis in celiac disease. PloS One. 2013;8(8):e70174.

81. Tello-Ruiz MK, Curley C, DelMonte T, Giallourakis C, Kirby A, Miller K, et al. Haplotype-based association analysis of 56 functional candidate genes in the IBD6 locus on chromosome 19. European journal of human genetics: EJHG. 2006 Jun;14(6):780-790.

82. van der Pouw Kraan TCTM, Zwiers A, Mulder CJ, Kraal G, Bouma G. Acute experimental colitis and human chronic inflammatory diseases share expression of inflammation-related genes with conserved Ets2 binding sites. Inflammatory Bowel Diseases. 2009 Feb;15(2):224-235.

83. van Heel DA, Franke L, Hunt KA, Gwilliam R, Zhernakova A, Inouye M, et al. A genome-wide association study for celiac disease identifies risk variants in the region harboring IL2 and IL21. Nature Genetics. 2007 Jul;39(7):827-829.

84. Zhernakova A, Stahl EA, Trynka G, Raychaudhuri S, Festen EA, Franke L, et al. Meta-analysis of 
bioRxiv preprint doi: https://doi.org/10.1101/2021.04.06.438717; this version posted April 15, 2021. The copyright holder for this preprint (which was not certified by peer review) is the author/funder, who has granted bioRxiv a license to display the preprint in perpetuity. It is made available under aCC-BY-NC-ND 4.0 International license.

genome-wide association studies in celiac disease and rheumatoid arthritis identifies fourteen non-HLA shared loci. PLoS genetics. 2011 Feb;7(2):e1002004.

85. Alonso A, Domènech E, Julià A, Panés J, García-Sánchez V, Mateu PN, et al. Identification of risk loci for Crohn's disease phenotypes using a genome-wide association study. Gastroenterology. 2015 Apr;148(4):794-805.

86. Barrett JC, Hansoul S, Nicolae DL, Cho JH, Duerr RH, Rioux JD, et al. Genome-wide association defines more than 30 distinct susceptibility loci for Crohn's disease. Nature Genetics. 2008 Aug;40(8):955-962.

87. Dubinsky MC, Kugathasan S, Kwon S, Haritunians T, Wrobel I, Wahbeh G, et al. Multidimensional prognostic risk assessment identifies association between IL12B variation and surgery in Crohn's disease. Inflammatory Bowel Diseases. 2013 Jul;19(8):1662-1670.

88. Ellinghaus D, Ellinghaus E, Nair RP, Stuart PE, Esko T, Metspalu A, et al. Combined analysis of genome-wide association studies for Crohn disease and psoriasis identifies seven shared susceptibility loci. American Journal of Human Genetics. 2012 Apr;90(4):636-647.

89. Franke A, Fischer A, Nothnagel M, Becker C, Grabe N, Till A, et al. Genome-wide association analysis in sarcoidosis and Crohn's disease unravels a common susceptibility locus on 10p12.2. Gastroenterology. 2008 Oct;135(4):1207-1215.

90. Franke A, Balschun T, Sina C, Ellinghaus D, Häsler R, Mayr G, et al. Genome-wide association study for ulcerative colitis identifies risk loci at 7q22 and 22q13 (IL17REL). Nature Genetics. 2010 Apr;42(4):292-294.

91. Huang J, Ellinghaus D, Franke A, Howie B, Li Y. 1000 Genomes-based imputation identifies novel and refined associations for the Wellcome Trust Case Control Consortium phase 1 Data. European journal of human genetics: EJHG. 2012 Jul;20(7):801-805.

92. Jostins L, Ripke S, Weersma RK, Duerr RH, McGovern DP, Hui KY, et al. Host-microbe interactions have shaped the genetic architecture of inflammatory bowel disease. Nature. 2012 Nov;491(7422):119-124.

93. Jung ES, Cheon JH, Lee JH, Park SJ, Jang HW, Chung SH, et al. HLA-C*01 is a Risk Factor for Crohn's Disease. Inflammatory Bowel Diseases. 2016 Apr;22(4):796-806.

94. Kenny EE, Pe'er I, Karban A, Ozelius L, Mitchell AA, Ng SM, et al. A genome-wide scan of Ashkenazi Jewish Crohn's disease suggests novel susceptibility loci. PLoS genetics. 2012;8(3):e1002559.

95. Libioulle C, Louis E, Hansoul S, Sandor C, Farnir F, Franchimont D, et al. Novel Crohn disease locus identified by genome-wide association maps to a gene desert on $5 \mathrm{p} 13.1$ and modulates expression of PTGER4. PLoS genetics. 2007 Apr;3(4):e58.

96. McGovern DPB, Jones MR, Taylor KD, Marciante K, Yan X, Dubinsky M, et al. Fucosyltransferase 2 (FUT2) non-secretor status is associated with Crohn's disease. Human Molecular Genetics. 2010 Sep;19(17):3468-3476

97. Okada Y, Yamazaki K, Umeno J, Takahashi A, Kumasaka N, Ashikawa K, et al. HLA-Cw*1202-B*5201-DRB1*1502 haplotype increases risk for ulcerative colitis but reduces risk for Crohn's disease. Gastroenterology. 2011 Sep;141(3):864-871.e1-5.

98. Parkes M, Barrett JC, Prescott NJ, Tremelling M, Anderson CA, Fisher SA, et al. Sequence variants in the autophagy gene IRGM and multiple other replicating loci contribute to Crohn's disease susceptibility. Nature Genetics. 2007 Jul;39(7):830-832.

99. Raelson JV, Little RD, Ruether A, Fournier H, Paquin B, Van Eerdewegh P, et al. Genome-wide association study for Crohn's disease in the Quebec Founder Population identifies multiple validated disease loci. Proceedings of the National Academy of Sciences of the United States of America. 2007 Sep;104(37):14747-14752.

100. Rioux JD, Xavier RJ, Taylor KD, Silverberg MS, Goyette P, Huett A, et al. Genome-wide association study identifies new susceptibility loci for Crohn disease and implicates autophagy in disease pathogenesis. Nature Genetics. 2007 May;39(5):596-604.

101. Yamazaki K, Umeno J, Takahashi A, Hirano A, Johnson TA, Kumasaka N, et al. A genome-wide association study identifies 2 susceptibility Loci for Crohn's disease in a Japanese population. Gastroenterology. 2013 Apr;144(4):781-788.

102. Yang SK, Hong M, Zhao W, Jung Y, Baek J, Tayebi N, et al. Genome-wide association study of Crohn's disease in Koreans revealed three new susceptibility loci and common attributes of genetic susceptibility across ethnic populations. Gut. 2014 Jan;63(1):80-87.

103. Baurecht H, Hotze M, Brand S, Büning C, Cormican P, Corvin A, et al. Genome-wide comparative analysis of atopic dermatitis and psoriasis gives insight into opposing genetic mechanisms. American Journal of Human Genetics. 2015 Jan;96(1):104-120.

104. Capon F, Bijlmakers MJ, Wolf N, Quaranta M, Huffmeier U, Allen M, et al. Identification of ZNF313/RNF114 as a novel psoriasis susceptibility gene. Human Molecular Genetics. 2008 Jul;17(13):1938-1945

105. Ellinghaus E, Ellinghaus D, Stuart PE, Nair RP, Debrus S, Raelson JV, et al. Genome-wide association study identifies a psoriasis susceptibility locus at TRAF3IP2. Nature Genetics. 2010 Nov;42(11):991-995.

106. Ellinghaus E, Stuart PE, Ellinghaus D, Nair RP, Debrus S, Raelson JV, et al. Genome-wide meta-analysis of psoriatic arthritis identifies susceptibility locus at REL. The Journal of Investigative Dermatology. 2012 Apr;132(4):1133-1140.

107. Genetic Analysis of Psoriasis Consortium \& the Wellcome Trust Case Control Consortium 2, Strange A, Capon F, Spencer CCA, Knight J, Weale ME, et al. A genome-wide association study identifies new psoriasis susceptibility loci and an interaction between HLA-C and ERAP1. Nature Genetics. 2010 Nov;42(11):985-990.

108. Haider AS, Lowes MA, Suárez-Fariñas M, Zaba LC, Cardinale I, Khatcherian A, et al. Identification of cellula pathways of "type 1," Th17 T cells, and TNF- and inducible nitric oxide synthase-producing dendritic cells in autoimmune inflammation through pharmacogenomic study of cyclosporine $A$ in psoriasis. Journal of Immunology (Baltimore, Md: 1950). 2008 Feb;180(3):1913-1920.

109. Hüffmeier U, Uebe S, Ekici AB, Bowes J, Giardina E, Korendowych E, et al. Common variants at TRAF3IP2 are associated with susceptibility to psoriatic arthritis and psoriasis. Nature Genetics. 2010 Nov;42(11):996-999. 
bioRxiv preprint doi: https://doi.org/10.1101/2021.04.06.438717; this version posted April 15, 2021. The copyright holder for this preprint (which was not certified by peer review) is the author/funder, who has granted bioRxiv a license to display the preprint in perpetuity. It is made available under aCC-BY-NC-ND 4.0 International license.

110. Li YR, Li J, Zhao SD, Bradfield JP, Mentch FD, Maggadottir SM, et al. Meta-analysis of shared genetic architecture across ten pediatric autoimmune diseases. Nature Medicine. 2015 Sep;21(9):1018-1027.

111. Liu Y, Helms C, Liao W, Zaba LC, Duan S, Gardner J, et al. A genome-wide association study of psoriasis and psoriatic arthritis identifies new disease loci. PLoS genetics. 2008 Mar;4(3):e1000041.

112. Nair RP, Duffin KC, Helms C, Ding J, Stuart PE, Goldgar D, et al. Genome-wide scan reveals association of psoriasis with IL-23 and NF-kappaB pathways. Nature Genetics. 2009 Feb;41(2):199-204.

113. Stuart PE, Nair RP, Tsoi LC, Tejasvi T, Das S, Kang HM, et al. Genome-wide Association Analysis of Psoriatic Arthritis and Cutaneous Psoriasis Reveals Differences in Their Genetic Architecture. American Journal of Human Genetics. 2015 Dec;97(6):816-836.

114. Stuart PE, Nair RP, Ellinghaus E, Ding J, Tejasvi T, Gudjonsson JE, et al. Genome-wide association analysis identifies three psoriasis susceptibility loci. Nature Genetics. 2010 Nov;42(11):1000-1004.

115. Tsoi LC, Spain SL, Ellinghaus E, Stuart PE, Capon F, Knight J, et al. Enhanced meta-analysis and replication studies identify five new psoriasis susceptibility loci. Nature Communications. 2015 May;6:7001.

116. Yin X, Low HQ, Wang L, Li Y, Ellinghaus E, Han J, et al. Genome-wide meta-analysis identifies multiple novel associations and ethnic heterogeneity of psoriasis susceptibility. Nature Communications. 2015 Apr;6:6916.

117. Zhang XJ, Huang W, Yang S, Sun LD, Zhang FY, Zhu QX, et al. Psoriasis genome-wide association study identifies susceptibility variants within LCE gene cluster at 1q21. Nature Genetics. 2009 Feb;41(2):205-210

118. Awata T, Yamashita H, Kurihara S, Morita-Ohkubo T, Miyashita Y, Katayama S, et al. A genome-wide association study for diabetic retinopathy in a Japanese population: potential association with a long intergenic non-coding RNA. PloS One. 2014;9(11):e111715.

119. Blackman SM, Commander CW, Watson C, Arcara KM, Strug LJ, Stonebraker JR, et al. Genetic modifiers of cystic fibrosis-related diabetes. Diabetes. 2013 Oct;62(10):3627-3635.

120. Burdon KP, Fogarty RD, Shen W, Abhary S, Kaidonis G, Appukuttan B, et al. Genome-wide association study for sight-threatening diabetic retinopathy reveals association with genetic variation near the GRB2 gene. Diabetologia. 2015 Oct;58(10):2288-2297.

121. Germain M, Pezzolesi MG, Sandholm N, McKnight AJ, Susztak K, Lajer M, et al. SORBS1 gene, a new candidate for diabetic nephropathy: results from a multi-stage genome-wide association study in patients with type 1 diabetes. Diabetologia. 2015 Mar;58(3):543-548.

122. Grassi MA, Tikhomirov A, Ramalingam S, Below JE, Cox NJ, Nicolae DL. Genome-wide meta-analysis for severe diabetic retinopathy. Human Molecular Genetics. 2011 Jun;20(12):2472-2481.

123. Hanson RL, Muller YL, Kobes S, Guo T, Bian L, Ossowski V, et al. A genome-wide association study in American Indians implicates DNER as a susceptibility locus for type 2 diabetes. Diabetes. 2014 Jan;63(1):369-376.

124. Huang YC, Lin JM, Lin HJ, Chen CC, Chen SY, Tsai CH, et al. Genome-wide association study of diabetic retinopathy in a Taiwanese population. Ophthalmology. 2011 Apr;118(4):642-648.

125. Imamura M, Maeda S, Yamauchi T, Hara K, Yasuda K, Morizono T, et al. A single-nucleotide polymorphism in ANK1 is associated with susceptibility to type 2 diabetes in Japanese populations. Human Molecular Genetics. 2012 Jul;21(13):3042-3049.

126. lyengar SK, Sedor JR, Freedman BI, Kao WHL, Kretzler M, Keller BJ, et al. Genome-Wide Association and Trans-ethnic Meta-Analysis for Advanced Diabetic Kidney Disease: Family Investigation of Nephropathy and Diabetes (FIND). PLoS genetics. 2015 Aug;11(8):e1005352.

127. Kwak SH, Kim SH, Cho YM, Go MJ, Cho YS, Choi SH, et al. A genome-wide association study of gestational diabetes mellitus in Korean women. Diabetes. 2012 Feb;61(2):531-541.

128. Li H, Gan W, Lu L, Dong X, Han X, Hu C, et al. A genome-wide association study identifies GRK5 and RASGRP1 as type 2 diabetes loci in Chinese Hans. Diabetes. 2013 Jan;62(1):291-298.

129. Maeda S, Osawa N, Hayashi T, Tsukada S, Kobayashi M, Kikkawa R. Genetic variations associated with diabetic nephropathy and type II diabetes in a Japanese population. Kidney International Supplement. 2007 Aug;(106):S43-48.

130. McDonough CW, Palmer ND, Hicks PJ, Roh BH, An SS, Cooke JN, et al. A genome-wide association study for diabetic nephropathy genes in African Americans. Kidney International. 2011 Mar;79(5):563-572.

131. Meng W, Deshmukh HA, Donnelly LA, Wellcome Trust Case Control Consortium 2 (WTCCC2), Surrogate markers for Micro- and Macro-vascular hard endpoints for Innovative diabetes Tools (SUMMIT) study group, Torrance N, et al. A Genome-wide Association Study Provides Evidence of Sex-specific Involvement of Chr1p35.1 (ZSCAN20-TLR12P) and Chr8p23.1 (HMGB1P46) With Diabetic Neuropathic Pain. EBioMedicine. 2015 Oct;2(10):1386-1393.

132. Perry JRB, Voight BF, Yengo L, Amin N, Dupuis J, Ganser M, et al. Stratifying type 2 diabetes cases by BMI identifies genetic risk variants in LAMA1 and enrichment for risk variants in lean compared to obese cases. PLoS genetics. 2012 May;8(5):e1002741.

133. Saxena R, Saleheen D, Been LF, Garavito ML, Braun T, Bjonnes A, et al. Genome-wide association study identifies a novel locus contributing to type 2 diabetes susceptibility in Sikhs of Punjabi origin from India. Diabetes. 2013 May;62(5):1746-1755.

134. SIGMA Type 2 Diabetes Consortium, Williams AL, Jacobs SBR, Moreno-Macías H, Huerta-Chagoya A Churchhouse C, et al. Sequence variants in SLC16A11 are a common risk factor for type 2 diabetes in Mexico. Nature. 2014 Feb;506(7486):97-101.

135. Tabassum R, Chauhan G, Dwivedi OP, Mahajan A, Jaiswal A, Kaur I, et al. Genome-wide association study for type 2 diabetes in Indians identifies a new susceptibility locus at 2q21. Diabetes. 2013 Mar;62(3):977-986.

136. Takeuchi F, Serizawa M, Yamamoto K, Fujisawa T, Nakashima E, Ohnaka K, et al. Confirmation of multiple risk Loci and genetic impacts by a genome-wide association study of type 2 diabetes in the Japanese population. Diabetes. 2009 Jul;58(7):1690-1699.

137. Timpson NJ, Lindgren CM, Weedon MN, Randall J, Ouwehand WH, Strachan DP, et al. Adiposity-related heterogeneity in patterns of type 2 diabetes susceptibility observed in genome-wide association data. Diabetes. 2009 Feb;58(2):505-510. 
bioRxiv preprint doi: https://doi.org/10.1101/2021.04.06.438717; this version posted April 15, 2021. The copyright holder for this preprint (which was not certified by peer review) is the author/funder, who has granted bioRxiv a license to display the preprint in perpetuity. It is made available under aCC-BY-NC-ND 4.0 International license.

138. Fischer A, Schmid B, Ellinghaus D, Nothnagel M, Gaede KI, Schürmann M, et al. A novel sarcoidosis risk locus for Europeans on chromosome 11q13.1. American Journal of Respiratory and Critical Care Medicine. 2012 Nov;186(9):877-885.

139. Hofmann S, Fischer A, Nothnagel M, Jacobs G, Schmid B, Wittig M, et al. Genome-wide association analysis reveals 12q13.3-q14.1 as new risk locus for sarcoidosis. The European Respiratory Journal. 2013 Apr;41(4):888-900.

140. Miller FW, Chen W, O'Hanlon TP, Cooper RG, Vencovsky J, Rider LG, et al. Genome-wide association study identifies HLA 8.1 ancestral haplotype alleles as major genetic risk factors for myositis phenotypes. Genes and Immunity. 2015 Oct;16(7):470-480.

141. Allanore Y, Saad M, Dieudé P, Avouac J, Distler JHW, Amouyel P, et al. Genome-wide scan identifies TNIP1, PSORS1C1, and RHOB as novel risk loci for systemic sclerosis. PLoS genetics. 2011 Jul;7(7):e1002091.

142. Gorlova O, Martin JE, Rueda B, Koeleman BPC, Ying J, Teruel M, et al. Identification of novel genetic markers associated with clinical phenotypes of systemic sclerosis through a genome-wide association strategy. PLoS genetics. 2011 Jul;7(7):e1002178.

143. Martin JE, Assassi S, Diaz-Gallo LM, Broen JC, Simeon CP, Castellvi I, et al. A systemic sclerosis and systemic lupus erythematosus pan-meta-GWAS reveals new shared susceptibility loci. Human Molecular Genetics. 2013 Oct;22(19):4021-4029.

144. Radstake TRDJ, Gorlova O, Rueda B, Martin JE, Alizadeh BZ, Palomino-Morales R, et al. Genome-wide association study of systemic sclerosis identifies CD247 as a new susceptibility locus. Nature Genetics. 2010 May;42(5):426-429.

145. Petukhova L, Duvic M, Hordinsky M, Norris D, Price V, Shimomura Y, et al. Genome-wide association study in alopecia areata implicates both innate and adaptive immunity. Nature. 2010 Jul;466(7302):113-117.

146. Schormair B, Kemlink D, Roeske D, Eckstein G, Xiong L, Lichtner P, et al. PTPRD (protein tyrosine phosphatase receptor type delta) is associated with restless legs syndrome. Nature Genetics. 2008 Aug;40(8):946-948.

147. Stefansson H, Rye DB, Hicks A, Petursson H, Ingason A, Thorgeirsson TE, et al. A genetic risk factor for periodic limb movements in sleep. The New England Journal of Medicine. 2007 Aug;357(7):639-647.

148. Winkelmann J, Czamara D, Schormair B, Knauf F, Schulte EC, Trenkwalder C, et al. Genome-wide association study identifies novel restless legs syndrome susceptibility loci on $2 \mathrm{p} 14$ and $16 \mathrm{q} 12.1$. PLoS genetics. $2011 \mathrm{Jul} ; 7(7): \mathrm{e} 1002171$.

149. Winkelmann J, Schormair B, Lichtner P, Ripke S, Xiong L, Jalilzadeh S, et al. Genome-wide association study of restless legs syndrome identifies common variants in three genomic regions. Nature Genetics. 2007 Aug;39(8):1000-1006.

150. Clancy RM, Marion MC, Kaufman KM, Ramos PS, Adler A, International Consortium on Systemic Lupus Erythematosus Genetics, et al. Identification of candidate loci at 6 p21 and 21q22 in a genome-wide association study of cardiac manifestations of neonatal lupus. Arthritis and Rheumatism. 2010 Nov;62(11):3415-3424.

151. Ramos-Casals M, Brito-Zeron P, Siso-Almirall A, Bosch X. Primary Sjogren syndrome. BMJ. 2012 Jun;344(jun14 1):e3821-e3821. Available from: http://www.bmj.com/cgi/doi/10.1136/bmj.e3821.

152. Song IW, Chen HC, Lin YF, Yang JH, Chang CC, Chou CT, et al. Identification of susceptibility gene associated with female primary Sjögren's syndrome in Han Chinese by genome-wide association study. Human Genetics. 2016 Nov;135(11):1287-1294.

153. Medici M, Porcu E, Pistis G, Teumer A, Brown SJ, Jensen RA, et al. Identification of novel genetic Loci associated with thyroid peroxidase antibodies and clinical thyroid disease. PLoS genetics. 2014 Feb;10(2):e1004123.

154. Oryoji D, Ueda S, Yamamoto K, Yoshimura Noh J, Okamura K, Noda M, et al. Identification of a Hashimoto thyroiditis susceptibility locus via a genome-wide comparison with Graves' disease. The Journal of Clinica Endocrinology and Metabolism. 2015 Feb;100(2):E319-324.

155. Duncan EL, Danoy P, Kemp JP, Leo PJ, McCloskey E, Nicholson GC, et al. Genome-wide association study using extreme truncate selection identifies novel genes affecting bone mineral density and fracture risk. PLoS genetics. 2011 Apr;7(4):e1001372.

156. Australo-Anglo-American Spondyloarthritis Consortium (TASC), Reveille JD, Sims AM, Danoy P, Evans DM, Leo $\mathrm{P}$, et al. Genome-wide association study of ankylosing spondylitis identifies non-MHC susceptibility loci. Nature Genetics. 2010 Feb;42(2):123-127.

157. Evans DM, Spencer CCA, Pointon JJ, Su Z, Harvey D, Kochan G, et al. Interaction between ERAP1 and HLA-B27 in ankylosing spondylitis implicates peptide handling in the mechanism for HLA-B27 in disease susceptibility. Nature Genetics. 2011 Jul;43(8):761-767.

158. Lin Z, Bei JX, Shen M, Li Q, Liao Z, Zhang Y, et al. A genome-wide association study in Han Chinese identifies new susceptibility loci for ankylosing spondylitis. Nature Genetics. 2011 Dec;44(1):73-77.

159. Deng X, Sabino EC, Cunha-Neto E, Ribeiro AL, lanni B, Mady C, et al. Genome wide association study (GWAS) of Chagas cardiomyopathy in Trypanosoma cruzi seropositive subjects. PloS One. 2013;8(11):e79629.

160. Andlauer TFM, Buck D, Antony G, Bayas A, Bechmann L, Berthele A, et al. Novel multiple sclerosis susceptibility loci implicated in epigenetic regulation. Science Advances. 2016;2(6):e1501678.

161. Aulchenko YS, Hoppenbrouwers IA, Ramagopalan SV, Broer L, Jafari N, Hillert J, et al. Genetic variation in the KIF1B locus influences susceptibility to multiple sclerosis. Nature Genetics. 2008 Dec;40(12):1402-1403.

162. Australia and New Zealand Multiple Sclerosis Genetics Consortium (ANZgene). Genome-wide association study identifies new multiple sclerosis susceptibility loci on chromosomes 12 and 20. Nature Genetics. 2009 Jul;41(7):824-828.

163. Baranzini SE, Srinivasan R, Khankhanian P, Okuda DT, Nelson SJ, Matthews PM, et al. Genetic variation influences glutamate concentrations in brains of patients with multiple sclerosis. Brain: A Journal of Neurology. 2010 Sep;133(9):2603-2611.

164. Baranzini SE, Wang J, Gibson RA, Galwey N, Naegelin Y, Barkhof F, et al. Genome-wide association analysis of susceptibility and clinical phenotype in multiple sclerosis. Human Molecular Genetics. 2009 
bioRxiv preprint doi: https://doi.org/10.1101/2021.04.06.438717; this version posted April 15, 2021. The copyright holder for this preprint (which was not certified by peer review) is the author/funder, who has granted bioRxiv a license to display the preprint in perpetuity. It is made available under aCC-BY-NC-ND 4.0 International license.

Feb;18(4):767-778

165. Brynedal B, Wojcik J, Esposito F, Debailleul V, Yaouanq J, Martinelli-Boneschi F, et al. MGAT5 alters the severity of multiple sclerosis. Journal of Neuroimmunology. 2010 Mar;220(1-2):120-124.

166. Comabella M, Craig DW, Camiña-Tato M, Morcillo C, Lopez C, Navarro A, et al. Identification of a novel risk locus for multiple sclerosis at $13 q 31.3$ by a pooled genome-wide scan of 500,000 single nucleotide polymorphisms. PloS One. 2008;3(10):e3490.

167. De Jager PL, Jia X, Wang J, de Bakker PIW, Ottoboni L, Aggarwal NT, et al. Meta-analysis of genome scans and replication identify CD6, IRF8 and TNFRSF1A as new multiple sclerosis susceptibility loci. Nature Genetics. 2009 Jul;41(7):776-782.

168. Goris A, Pauwels I, Gustavsen MW, van Son B, Hilven K, Bos SD, et al. Genetic variants are major determinants of CSF antibody levels in multiple sclerosis. Brain: A Journal of Neurology. $2015 \mathrm{Mar} ; 138(\mathrm{Pt}$ 3):632-643.

169. Goris A, van Setten J, Diekstra F, Ripke S, Patsopoulos NA, Sawcer SJ, et al. No evidence for shared genetic basis of common variants in multiple sclerosis and amyotrophic lateral sclerosis. Human Molecular Genetics. 2014 Apr;23(7):1916-1922.

170. Gourraud PA, Sdika M, Khankhanian P, Henry RG, Beheshtian A, Matthews PM, et al. A genome-wide association study of brain lesion distribution in multiple sclerosis. Brain: A Journal of Neurology. 2013 Apr;136(Pt 4):1012-1024.

171. International Multiple Sclerosis Genetics Consortium, Wellcome Trust Case Control Consortium 2, Sawcer S, Hellenthal G, Pirinen M, Spencer CCA, et al. Genetic risk and a primary role for cell-mediated immune mechanisms in multiple sclerosis. Nature. 2011 Aug;476(7359):214-219.

172. International Multiple Sclerosis Genetics Consortium. Genome-wide association study of severity in multiple sclerosis. Genes and Immunity. 2011 Dec;12(8):615-625.

173. International Multiple Sclerosis Genetics Consortium, Hafler DA, Compston A, Sawcer S, Lander ES, Daly MJ, et al. Risk alleles for multiple sclerosis identified by a genomewide study. The New England Journal of Medicine. 2007 Aug;357(9):851-862.

174. Jakkula E, Leppä V, Sulonen AM, Varilo T, Kallio S, Kemppinen A, et al. Genome-wide association study in a high-risk isolate for multiple sclerosis reveals associated variants in STAT3 gene. American Journal of Human Genetics. 2010 Feb;86(2):285-291.

175. Leone MA, Barizzone N, Esposito F, Lucenti A, Harbo HF, Goris A, et al. Association of genetic markers with CSF oligoclonal bands in multiple sclerosis patients. PloS One. 2013;8(6):e64408.

176. Martinelli-Boneschi F, Esposito F, Brambilla P, Lindström E, Lavorgna G, Stankovich J, et al. A genome-wide association study in progressive multiple sclerosis. Multiple Sclerosis (Houndmills, Basingstoke, England). 2012 Oct; 18(10):1384-1394.

177. Matesanz F, González-Pérez A, Lucas M, Sanna S, Gayán J, Urcelay E, et al. Genome-wide association study of multiple sclerosis confirms a novel locus at 5p13.1. PloS One. 2012;7(5):e36140.

178. Mero IL, Gustavsen MW, Sæther HS, Flåm ST, Berg-Hansen P, Søndergaard HB, et al. Oligoclonal band status in Scandinavian multiple sclerosis patients is associated with specific genetic risk alleles. PloS One. 2013;8(3):e58352.

179. Nischwitz S, Cepok S, Kroner A, Wolf C, Knop M, Müller-Sarnowski F, et al. Evidence for VAV2 and ZNF433 as susceptibility genes for multiple sclerosis. Journal of Neuroimmunology. 2010 Oct;227(1-2):162-166.

180. Patsopoulos NA, Bayer Pharma MS Genetics Working Group, Steering Committees of Studies Evaluating IFN-1b and a CCR1-Antagonist, ANZgene Consortium, GeneMSA, International Multiple Sclerosis Genetics Consortium, et al. Genome-wide meta-analysis identifies novel multiple sclerosis susceptibility loci. Annals of Neurology. 2011 Dec;70(6):897-912.

181. Sanna S, Pitzalis M, Zoledziewska M, Zara I, Sidore C, Murru R, et al. Variants within the immunoregulatory CBLB gene are associated with multiple sclerosis. Nature Genetics. 2010 Jun;42(6):495-497.

182. Wang JH, Pappas D, De Jager PL, Pelletier D, de Bakker PI, Kappos L, et al. Modeling the cumulative genetic risk for multiple sclerosis from genome-wide association data. Genome Medicine. 2011 Jan;3(1):3.

183. Zhou Y, Zhu G, Charlesworth JC, Simpson S, Rubicz R, Göring HH, et al. Genetic loci for Epstein-Barr virus nuclear antigen-1 are associated with risk of multiple sclerosis. Multiple Sclerosis (Houndmills, Basingstoke, England). 2016;22(13):1655-1664.

184. Adachi S, Tajima A, Quan J, Haino K, Yoshihara K, Masuzaki H, et al. Meta-analysis of genome-wide association scans for genetic susceptibility to endometriosis in Japanese population. Journal of Human Genetics. 2010 Dec;55(12):816-821.

185. Albertsen HM, Chettier R, Farrington P, Ward K. Genome-wide association study link novel loci to endometriosis. PloS One. 2013;8(3):e58257.

186. Nyholt DR, Low SK, Anderson CA, Painter JN, Uno S, Morris AP, et al. Genome-wide association meta-analysis identifies new endometriosis risk loci. Nature Genetics. 2012 Dec;44(12):1355-1359.

187. Painter JN, Anderson CA, Nyholt DR, Macgregor S, Lin J, Lee SH, et al. Genome-wide association study identifies a locus at 7p15.2 associated with endometriosis. Nature Genetics. 2011 Jan;43(1):51-54.

188. Uno S, Zembutsu H, Hirasawa A, Takahashi A, Kubo M, Akahane T, et al. A genome-wide association study identifies genetic variants in the CDKN2BAS locus associated with endometriosis in Japanese. Nature Genetics. 2010 Aug;42(8):707-710

189. Wang W, Li Y, Li S, Wu Z, Yuan M, Wang T, et al. Pooling-Based Genome-Wide Association Study Identifies Risk Loci in the Pathogenesis of Ovarian Endometrioma in Chinese Han Women. Reproductive Sciences (Thousand Oaks, Calif). 2017;24(3):400-406.

190. Anderson CA, Boucher G, Lees CW, Franke A, D'Amato M, Taylor KD, et al. Meta-analysis identifies 29 additional ulcerative colitis risk loci, increasing the number of confirmed associations to 47 . Nature Genetics. $2011 \mathrm{Mar} ; 43(3): 246-252$

191. Asano K, Matsushita T, Umeno J, Hosono N, Takahashi A, Kawaguchi T, et al. A genome-wide association study identifies three new susceptibility loci for ulcerative colitis in the Japanese population. Nature Genetics. 
bioRxiv preprint doi: https://doi.org/10.1101/2021.04.06.438717; this version posted April 15, 2021. The copyright holder for this preprint (which was not certified by peer review) is the author/funder, who has granted bioRxiv a license to display the preprint in perpetuity. It is made available under aCC-BY-NC-ND 4.0 International license.

2009 Dec;41(12):1325-1329.

192. Burczynski ME, Peterson RL, Twine NC, Zuberek KA, Brodeur BJ, Casciotti L, et al. Molecular classification of Crohn's disease and ulcerative colitis patients using transcriptional profiles in peripheral blood mononuclear cells. The Journal of molecular diagnostics: JMD. 2006 Feb;8(1):51-61.

193. Ellinghaus D, Folseraas T, Holm K, Ellinghaus E, Melum E, Balschun T, et al. Genome-wide association analysis in primary sclerosing cholangitis and ulcerative colitis identifies risk loci at GPR35 and TCF4. Hepatology (Baltimore, Md). 2013 Sep;58(3):1074-1083.

194. Flach CF, Eriksson A, Jennische E, Lange S, Gunnerek C, Lönnroth I. Detection of elafin as a candidate biomarker for ulcerative colitis by whole-genome microarray screening. Inflammatory Bowel Diseases. 2006 Sep;12(9):837-842.

195. Franke A, Balschun T, Karlsen TH, Sventoraityte J, Nikolaus S, Mayr G, et al. Sequence variants in IL10, ARPC2 and multiple other loci contribute to ulcerative colitis susceptibility. Nature Genetics. 2008 Nov;40(11):1319-1323.

196. Haritunians T, Taylor KD, Targan SR, Dubinsky M, Ippoliti A, Kwon S, et al. Genetic predictors of medically refractory ulcerative colitis. Inflammatory Bowel Diseases. 2010 Nov;16(11):1830-1840.

197. Julià $A$, Domènech $E$, Chaparro $M$, García-Sánchez V, Gomollón $F$, Panés J, et al. A genome-wide association study identifies a novel locus at 6q22.1 associated with ulcerative colitis. Human Molecular Genetics. 2014 Dec;23(25):6927-6934

198. Juyal G, Negi S, Sood A, Gupta A, Prasad P, Senapati S, et al. Genome-wide association scan in north Indians reveals three novel HLA-independent risk loci for ulcerative colitis. Gut. 2015 Apr;64(4):571-579.

199. Liu JZ, van Sommeren S, Huang H, Ng SC, Alberts R, Takahashi A, et al. Association analyses identify 38 susceptibility loci for inflammatory bowel disease and highlight shared genetic risk across populations. Nature Genetics. 2015 Sep;47(9):979-986.

200. McGovern DPB, Gardet A, Törkvist L, Goyette P, Essers J, Taylor KD, et al. Genome-wide association identifies multiple ulcerative colitis susceptibility loci. Nature Genetics. 2010 Apr;42(4):332-337.

201. Okahara S, Arimura Y, Yabana T, Kobayashi K, Gotoh A, Motoya S, et al. Inflammatory gene signature in ulcerative colitis with cDNA macroarray analysis. Alimentary Pharmacology \& Therapeutics. 2005 May;21(9):1091-1097.

202. Silverberg MS, Cho JH, Rioux JD, McGovern DPB, Wu J, Annese V, et al. Ulcerative colitis-risk loci on chromosomes 1p36 and 12q15 found by genome-wide association study. Nature Genetics. 2009 Feb;41(2):216-220.

203. UK IBD Genetics Consortium, Barrett JC, Lee JC, Lees CW, Prescott NJ, Anderson CA, et al. Genome-wide association study of ulcerative colitis identifies three new susceptibility loci, including the HNF4A region. Nature Genetics. 2009 Dec;41(12):1330-1334.

204. Waller S, Tremelling M, Bredin F, Godfrey L, Howson J, Parkes M. Evidence for association of OCTN genes and IBD5 with ulcerative colitis. Gut. 2006 Jun;55(6):809-814.

205. Watanabe T, Kobunai T, Toda E, Kanazawa T, Kazama Y, Tanaka J, et al. Gene expression signature and the prediction of ulcerative colitis-associated colorectal cancer by DNA microarray. Clinical Cancer Research: An Official Journal of the American Association for Cancer Research. 2007 Jan;13(2 Pt 1):415-420.

206. Yang SK, Hong M, Zhao W, Jung Y, Tayebi N, Ye BD, et al. Genome-wide association study of ulcerative colitis in Koreans suggests extensive overlapping of genetic susceptibility with Caucasians. Inflammatory Bowel Diseases. 2013 Apr;19(5):954-966.

207. Zahn A, Moehle C, Langmann T, Ehehalt R, Autschbach F, Stremmel W, et al. Aquaporin-8 expression is reduced in ileum and induced in colon of patients with ulcerative colitis. World Journal of Gastroenterology. 2007 Mar;13(11):1687-1695.

208. Milton JN, Sebastiani P, Solovieff N, Hartley SW, Bhatnagar P, Arking DE, et al. A genome-wide association study of total bilirubin and cholelithiasis risk in sickle cell anemia. PloS One. 2012;7(4):e34741.

209. Alarcón-Riquelme ME, Ziegler JT, Molineros J, Howard TD, Moreno-Estrada A, Sánchez-Rodríguez E, et al. Genome-Wide Association Study in an Amerindian Ancestry Population Reveals Novel Systemic Lupus Erythematosus Risk Loci and the Role of European Admixture. Arthritis \& Rheumatology (Hoboken, NJ). 2016 Apr;68(4):932-943.

210. Armstrong DL, Zidovetzki R, Alarcón-Riquelme ME, Tsao BP, Criswell LA, Kimberly RP, et al. GWAS identifies novel SLE susceptibility genes and explains the association of the HLA region. Genes and Immunity. 2014 Sep;15(6):347-354.

211. Bentham J, Morris DL, Graham DSC, Pinder CL, Tombleson P, Behrens TW, et al. Genetic association analyses implicate aberrant regulation of innate and adaptive immunity genes in the pathogenesis of systemic lupus erythematosus. Nature Genetics. 2015 Dec;47(12):1457-1464.

212. Chung SA, Taylor KE, Graham RR, Nititham J, Lee AT, Ortmann WA, et al. Differential genetic associations for systemic lupus erythematosus based on anti-dsDNA autoantibody production. PLoS genetics. 2011 Mar;7(3): e1001323

213. Demirci FY, Wang X, Kelly JA, Morris DL, Barmada MM, Feingold E, et al. Identification of a New Susceptibility Locus for Systemic Lupus Erythematosus on Chromosome 12 in Individuals of European Ancestry. Arthritis \& Rheumatology (Hoboken, NJ). 2016 Jan;68(1):174-183.

214. Graham RR, Cotsapas C, Davies L, Hackett R, Lessard CJ, Leon JM, et al. Genetic variants near TNFAIP3 on 6q23 are associated with systemic lupus erythematosus. Nature Genetics. 2008 Sep;40(9):1059-1061.

215. Han JW, Zheng HF, Cui Y, Sun LD, Ye DQ, Hu Z, et al. Genome-wide association study in a Chinese Han population identifies nine new susceptibility loci for systemic lupus erythematosus. Nature Genetics. 2009 Nov; 41(11):1234-1237.

216. Hom G, Graham RR, Modrek B, Taylor KE, Ortmann W, Garnier S, et al. Association of systemic lupus erythematosus with C8orf13-BLK and ITGAM-ITGAX. The New England Journal of Medicine. 2008 Feb;358(9):900-909.

217. International Consortium for Systemic Lupus Erythematosus Genetics (SLEGEN), Harley JB, 
bioRxiv preprint doi: https://doi.org/10.1101/2021.04.06.438717; this version posted April 15, 2021. The copyright holder for this preprint (which was not certified by peer review) is the author/funder, who has granted bioRxiv a license to display the preprint in perpetuity. It is made available under aCC-BY-NC-ND 4.0 International license.

Alarcón-Riquelme ME, Criswell LA, Jacob CO, Kimberly RP, et al. Genome-wide association scan in women with systemic lupus erythematosus identifies susceptibility variants in ITGAM, PXK, KIAA1542 and other loci. Nature Genetics. 2008 Feb;40(2):204-210.

218. Kariuki SN, Ghodke-Puranik Y, Dorschner JM, Chrabot BS, Kelly JA, Tsao BP, et al. Genetic analysis of the pathogenic molecular sub-phenotype interferon-alpha identifies multiple novel loci involved in systemic lupus erythematosus. Genes and Immunity. 2015 Feb;16(1):15-23.

219. Kim K, Bang SY, Joo YB, Kim T, Lee HS, Kang C, et al. Response to Intravenous Cyclophosphamide Treatment for Lupus Nephritis Associated with Polymorphisms in the FCGR2B-FCRLA Locus. The Journal of Rheumatology. 2016;43(6):1045-1049.

220. Kozyrev SV, Abelson AK, Wojcik J, Zaghlool A, Linga Reddy MVP, Sanchez E, et al. Functional variants in the B-cell gene BANK1 are associated with systemic lupus erythematosus. Nature Genetics. 2008 Feb;40(2):211-216

221. Lee YH, Bae SC, Choi SJ, Ji JD, Song GG. Genome-wide pathway analysis of genome-wide association studies on systemic lupus erythematosus and rheumatoid arthritis. Molecular Biology Reports. 2012 Dec;39(12):10627-10635.

222. Lessard CJ, Sajuthi S, Zhao J, Kim K, Ice JA, Li H, et al. Identification of a Systemic Lupus Erythematosus Risk Locus Spanning ATG16L2, FCHSD2, and P2RY2 in Koreans. Arthritis \& Rheumatology (Hoboken, NJ) 2016;68(5):1197-1209.

223. Márquez A, Vidal-Bralo L, Rodríguez-Rodríguez L, González-Gay MA, Balsa A, González-Álvaro I, et al. A combined large-scale meta-analysis identifies COG6 as a novel shared risk locus for rheumatoid arthritis and systemic lupus erythematosus. Annals of the Rheumatic Diseases. 2017 Jan;76(1):286-294.

224. Morris DL, Sheng Y, Zhang Y, Wang YF, Zhu Z, Tombleson P, et al. Genome-wide association meta-analysis in Chinese and European individuals identifies ten new loci associated with systemic lupus erythematosus. Nature Genetics. 2016;48(8):940-946.

225. Okada Y, Shimane K, Kochi Y, Tahira T, Suzuki A, Higasa K, et al. A genome-wide association study identified AFF1 as a susceptibility locus for systemic lupus eyrthematosus in Japanese. PLoS genetics. 2012 Jan;8(1):e1002455.

226. Yang J, Yang W, Hirankarn N, Ye DQ, Zhang Y, Pan HF, et al. ELF1 is associated with systemic lupus erythematosus in Asian populations. Human Molecular Genetics. 2011 Feb;20(3):601-607.

227. Yang W, Shen N, Ye DQ, Liu Q, Zhang Y, Qian XX, et al. Genome-wide association study in Asian populations identifies variants in ETS1 and WDFY4 associated with systemic lupus erythematosus. PLoS genetics. 2010 Feb;6(2):e1000841.

228. Zhang Y, Yang J, Zhang J, Sun L, Hirankarn N, Pan HF, et al. Genome-wide search followed by replication reveals genetic interaction of CD80 and ALOX5AP associated with systemic lupus erythematosus in Asian populations. Annals of the Rheumatic Diseases. 2016 May;75(5):891-898.

229. Cordell HJ, Han Y, Mells GF, Li Y, Hirschfield GM, Greene CS, et al. International genome-wide meta-analysis identifies new primary biliary cirrhosis risk loci and targetable pathogenic pathways. Nature Communications. 2015 Sep;6:8019.

230. Garcia-Barceló MM, Yeung MY, Miao XP, Tang CSM, Cheng G, Chen G, et al. Genome-wide association study identifies a susceptibility locus for biliary atresia on 10q24.2. Human Molecular Genetics. 2010 Jul;19(14):2917-2925.

231. Hirschfield GM, Liu X, Xu C, Lu Y, Xie G, Lu Y, et al. Primary biliary cirrhosis associated with HLA, IL12A, and IL12RB2 variants. The New England Journal of Medicine. 2009 Jun;360(24):2544-2555.

232. Liu X, Invernizzi P, Lu Y, Kosoy R, Lu Y, Bianchi I, et al. Genome-wide meta-analyses identify three loci associated with primary biliary cirrhosis. Nature Genetics. 2010 Aug;42(8):658-660

233. Mells GF, Floyd JAB, Morley KI, Cordell HJ, Franklin CS, Shin SY, et al. Genome-wide association study identifies 12 new susceptibility loci for primary biliary cirrhosis. Nature Genetics. 2011 Mar;43(4):329-332.

234. Nakamura M, Nishida N, Kawashima M, Aiba Y, Tanaka A, Yasunami M, et al. Genome-wide association study identifies TNFSF15 and POU2AF1 as susceptibility loci for primary biliary cirrhosis in the Japanese population. American Journal of Human Genetics. 2012 Oct;91(4):721-728.

235. Chen PL, Shih SR, Wang PW, Lin YC, Chu CC, Lin JH, et al. Genetic determinants of antithyroid drug-induced agranulocytosis by human leukocyte antigen genotyping and genome-wide association study. Nature Communications. 2015 Jul;6:7633.

236. Chu X, Pan CM, Zhao SX, Liang J, Gao GQ, Zhang XM, et al. A genome-wide association study identifies two new risk loci for Graves' disease. Nature Genetics. 2011 Aug;43(9):897-901.

237. Khong JJ, Burdon KP, Lu Y, Leonardos L, Laurie KJ, Walsh JP, et al. Association of Polymorphisms in MACRO Domain Containing 2 With Thyroid-Associated Orbitopathy. Investigative Ophthalmology \& Visual Science. 2016;57(7):3129-3137.

238. Nakabayashi K, Tajima A, Yamamoto K, Takahashi A, Hata K, Takashima Y, et al. Identification of independent risk loci for Graves' disease within the MHC in the Japanese population. Journal of Human Genetics. 2011 Nov;56(11):772-778.

239. Zhao SX, Xue LQ, Liu W, Gu ZH, Pan CM, Yang SY, et al. Robust evidence for five new Graves' disease risk loci from a staged genome-wide association analysis. Human Molecular Genetics. 2013 Aug;22(16):3347-3362

240. Feehally J, Farrall M, Boland A, Gale DP, Gut I, Heath S, et al. HLA has strongest association with IgA nephropathy in genome-wide analysis. Journal of the American Society of Nephrology: JASN. 2010 Oct;21(10):1791-1797.

241. Gharavi AG, Kiryluk K, Choi M, Li Y, Hou P, Xie J, et al. Genome-wide association study identifies susceptibility loci for IgA nephropathy. Nature Genetics. 2011 Mar;43(4):321-327.

242. Kiryluk K, Li Y, Scolari F, Sanna-Cherchi S, Choi M, Verbitsky M, et al. Discovery of new risk loci for IgA nephropathy implicates genes involved in immunity against intestinal pathogens. Nature Genetics. 2014 Nov;46(11):1187-1196

243. Li M, Foo JN, Wang JQ, Low $H Q$, Tang $X Q$, Toh KY, et al. Identification of new susceptibility loci for IgA 
bioRxiv preprint doi: https://doi.org/10.1101/2021.04.06.438717; this version posted April 15, 2021. The copyright holder for this preprint (which was not certified by peer review) is the author/funder, who has granted bioRxiv a license to display the preprint in perpetuity. It is made available under aCC-BY-NC-ND 4.0 International license.

nephropathy in Han Chinese. Nature Communications. 2015 Jun;6:7270.

244. Yang C, Jie W, Yanlong Y, Xuefeng G, Aihua T, Yong G, et al. Genome-wide association study identifies TNFSF13 as a susceptibility gene for IgA in a South Chinese population in smokers. Immunogenetics. 2012 Oct:64(10):747-753.

245. Yu XQ, Li M, Zhang H, Low HQ, Wei X, Wang JQ, et al. A genome-wide association study in Han Chinese identifies multiple susceptibility loci for IgA nephropathy. Nature Genetics. 2011 Dec;44(2):178-182.

Figures

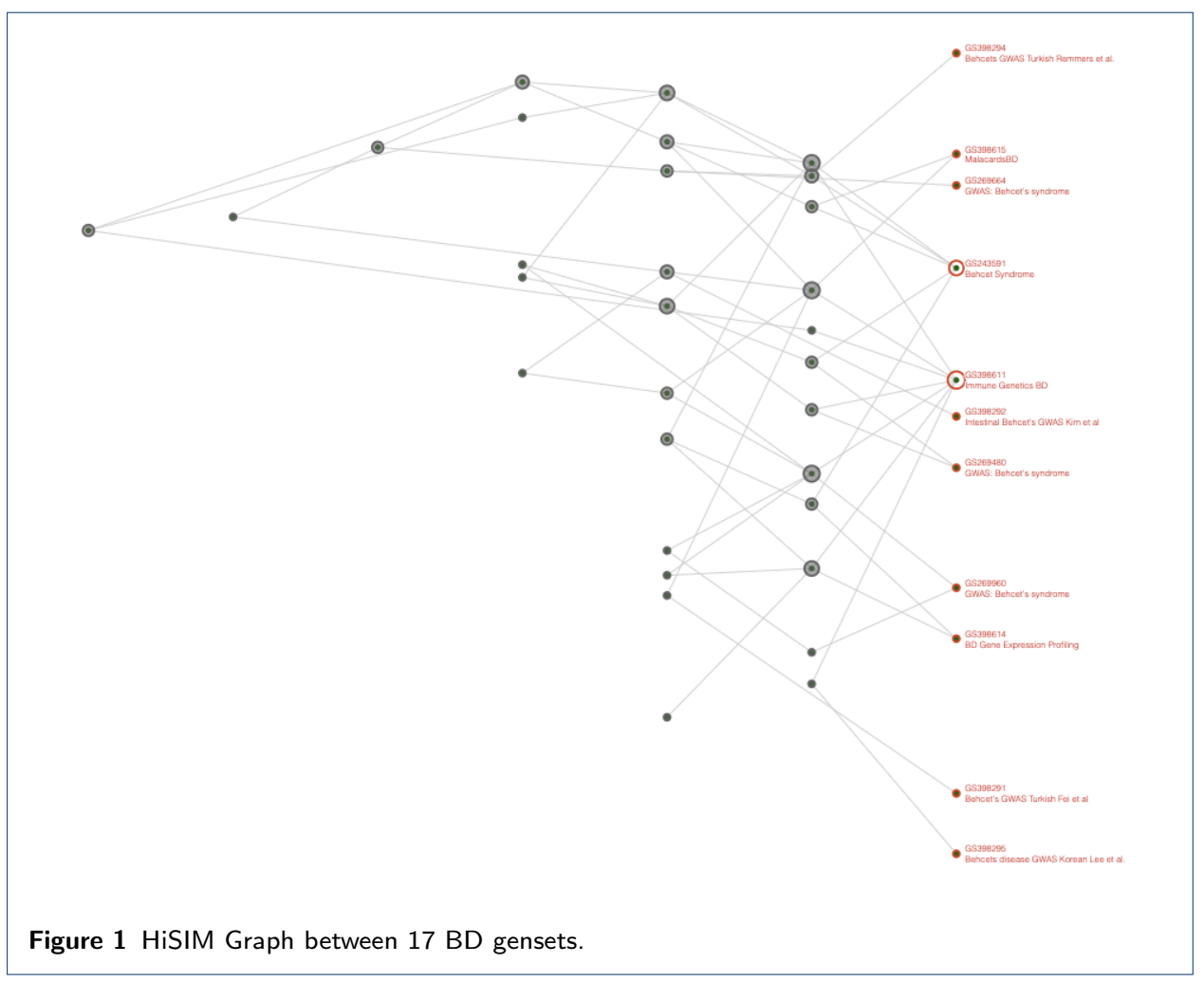


bioRxiv preprint doi: https://doi.org/10.1101/2021.04.06.438717; this version posted April 15, 2021. The copyright holder for this preprint (which was not certified by peer review) is the author/funder, who has granted bioRxiv a license to display the preprint in perpetuity. It is made available under aCC-BY-NC-ND 4.0 International license.
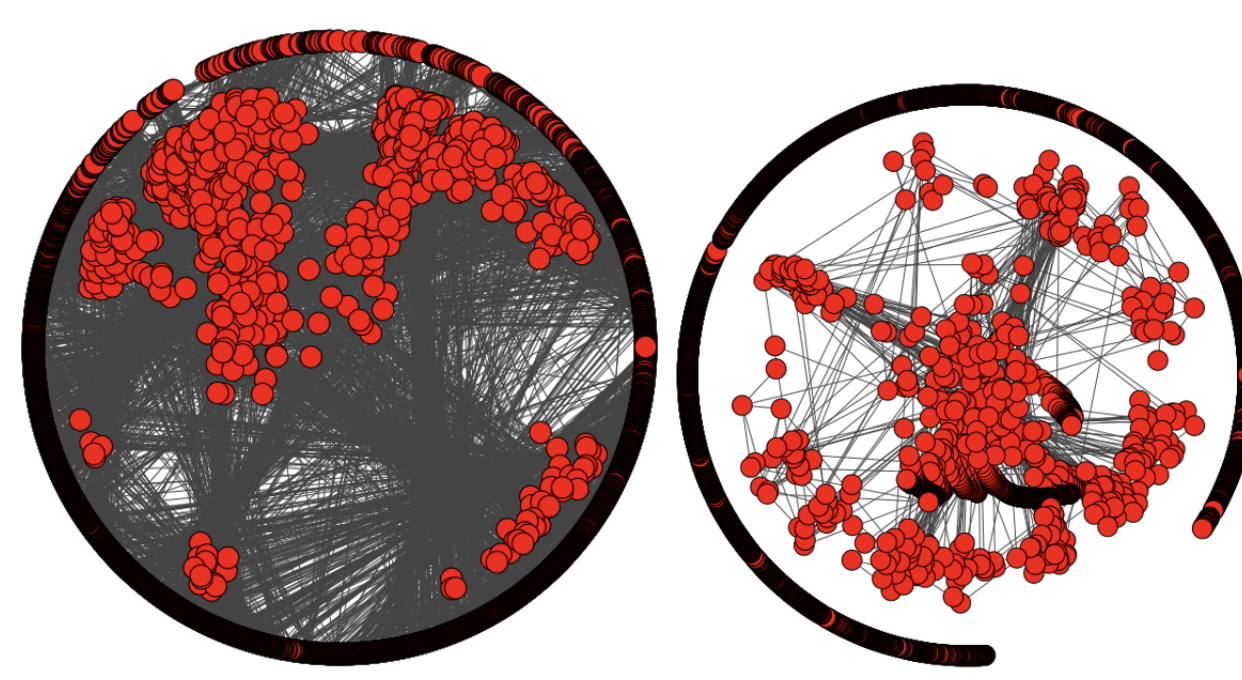

Figure 2 Results from the Autoimmune HiSIM Graph run. 27 autoimmune diseases were compared to BD in order to find which diseases had the largest genetic overlap with BD. A) All edges between computed nodes were drawn. B) Edges were filtered such that only edges that connected to nodes containing the BD geneset were drawn.

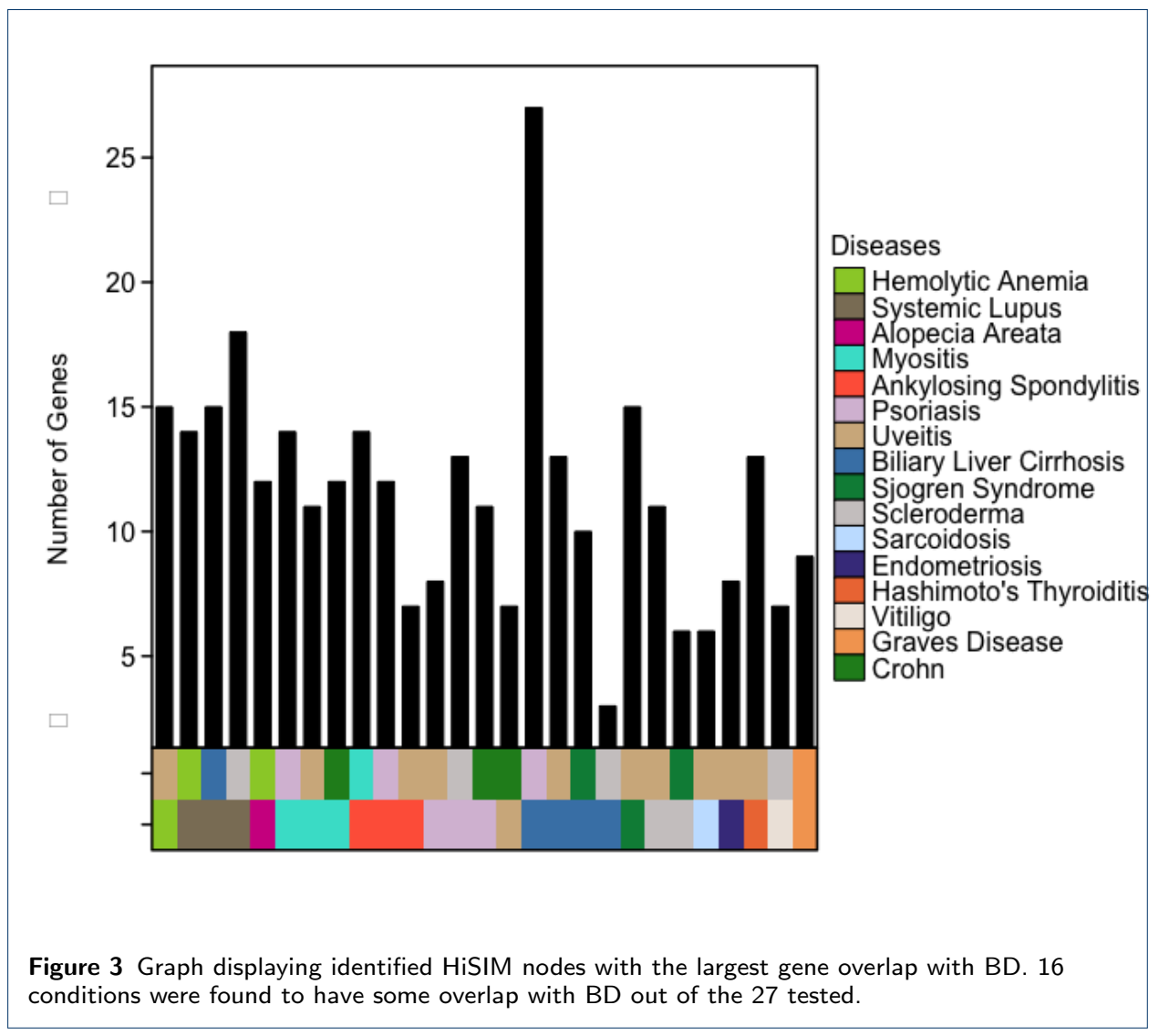


bioRxiv preprint doi: https://doi.org/10.1101/2021.04.06.438717; this version posted April 15, 2021. The copyright holder for this preprint (which was not certified by peer review) is the author/funder, who has granted bioRxiv a license to display the preprint in perpetuity. It is made available under aCC-BY-NC-ND 4.0 International license.

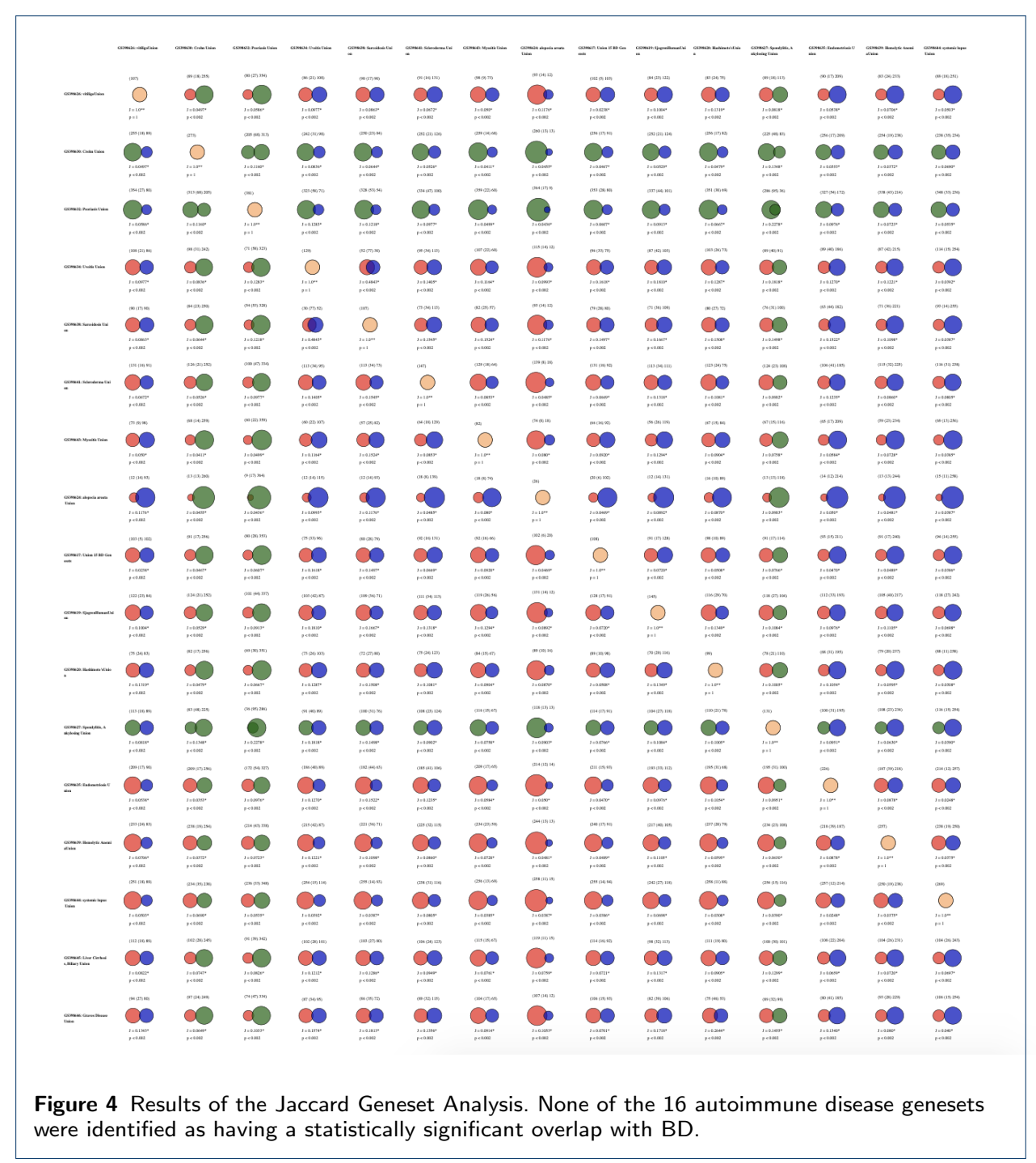


bioRxiv preprint doi: https://doi.org/10.1101/2021.04.06.438717; this version posted April 15, 2021. The copyright holder for this preprint (which was not certified by peer review) is the author/funder, who has granted bioRxiv a license to display the preprint in perpetuity. It is made available under aCC-BY-NC-ND 4.0 International license.

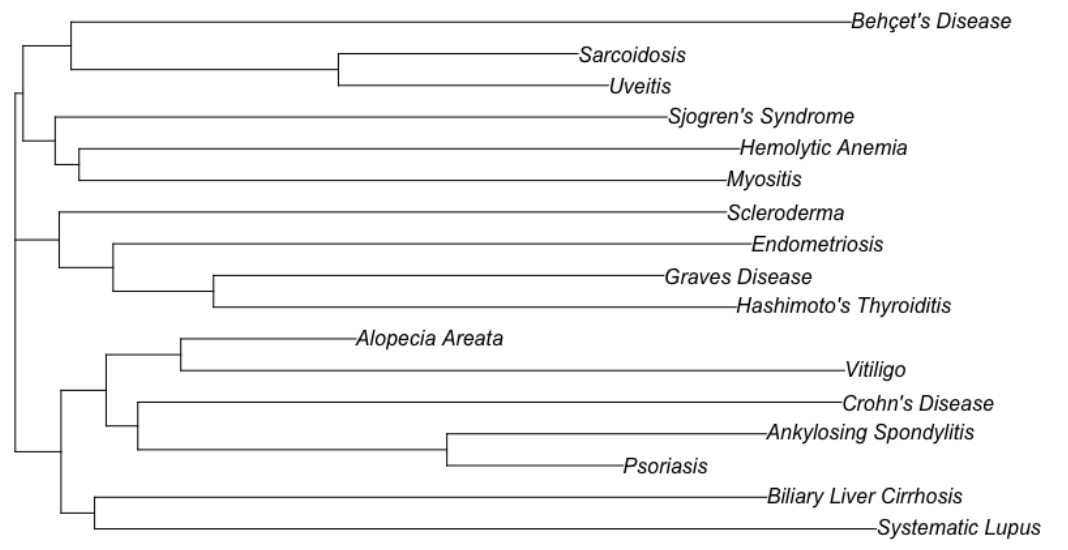

Figure 5 Results of the Neighbor Joining Tree. 
bioRxiv preprint doi: https://doi.org/10.1101/2021.04.06.438717; this version posted April 15, 2021. The copyright holder for this preprint (which was not certified by peer review) is the author/funder, who has granted bioRxiv a license to display the preprint in perpetuity. It is made available under aCC-BY-NC-ND 4.0 International license.

Tables

\begin{tabular}{|c|c|c|c|}
\hline Condition & $\begin{array}{l}\text { Number of } \\
\text { Genes }\end{array}$ & $\begin{array}{l}\text { Number of } \\
\text { Genesets }\end{array}$ & Publications \\
\hline Achalasia & 12 & 3 & {$[63]$} \\
\hline Vitiligo & 107 & 10 & {$[64,65,66,67,68,69,70]$} \\
\hline Celiac Disease & 428 & 22 & $\begin{array}{l}{[71,72,73,74,75,76,77,78,63,79,80,81,} \\
82,83,84]\end{array}$ \\
\hline Crohn's Disease & 273 & 25 & $\begin{array}{l}{[85,86,87,88,76,89,90,91,92,93,94,95,} \\
96,97,98,99,100,101,102]\end{array}$ \\
\hline Psoriasis & 382 & 23 & $\begin{array}{l}{[103,104,105,105,106,107,108,109,110,} \\
111,112,113,114,115,116,117]\end{array}$ \\
\hline Diabetes & 130 & 20 & $\begin{array}{l}{[118,119,120,121,122,123,124,125,126,127,} \\
128,129,130,131,132,133,134,135,136,137]\end{array}$ \\
\hline Uveitis & 130 & 7 & [63] \\
\hline Sarcoidosis & 107 & 7 & {$[138,89,139]$} \\
\hline Myositis & 82 & 5 & {$[63,140]$} \\
\hline Scleroderma & 148 & 9 & {$[141,142,63,143,144]$} \\
\hline Agammaglobulinemia & 39 & 3 & [63] \\
\hline Alopecia Areata & 26 & 3 & [145] \\
\hline Restless Leg Syndrome & 27 & 6 & {$[63,146,147,148,149]$} \\
\hline Sjogren Syndrome & 145 & 7 & {$[150,128,151,152]$} \\
\hline Hashimoto's Thyroiditis & 99 & 6 & {$[63,153,154]$} \\
\hline Addison Disease & 40 & 4 & [155] \\
\hline Amyloidosis & 58 & 12 & [63] \\
\hline Ankylosing Spondylitis & 132 & 6 & {$[156,157,79,158]$} \\
\hline Chagas Syndrome & 159 & 7 & [159] \\
\hline MS & 201 & 25 & $\begin{array}{l}{[160,161,162,163,164,165,166,167,168,169,} \\
170,171,172,173,174,175,176,177,178,179, \\
180,181,182,183]\end{array}$ \\
\hline Endometriosis & 226 & 9 & {$[184,185,63,186,187,188,189]$} \\
\hline Ulcerative Colitis & 386 & 23 & $\begin{array}{l}{[190,191,192,193,194,195,89,196,92,197,} \\
198,199,200,97,201,202,203,204,205,206, \\
207]\end{array}$ \\
\hline Hemolytic Anemia & 261 & 20 & {$[63,208]$} \\
\hline Systematic Lupus & 269 & 25 & $\begin{array}{l}{[209,210,211,212,150,213,214,215,216,217,} \\
218,219,220,221,222,223,143,224,225,226, \\
227,228]\end{array}$ \\
\hline Liver Cirrhosis & 130 & 8 & {$[229,230,231,63,232,233,234]$} \\
\hline Graves' Disease & 121 & 8 & {$[235,236,237,63,238,154,239]$} \\
\hline IgA nephropathy & 39 & 6 & {$[240,241,242,243,244,245]$} \\
\hline
\end{tabular}

Table 1 Genetic information from 27 autoimmune diseases were collected from multiple publicly available genesets on Geneweaver. Genesets from each condition were then consolidated into one geneset using the Boolean Algebra tool.

\begin{tabular}{|c|c|}
\hline Parameter & Value \\
\hline Disable Bootstrap & False \\
\hline Node Cutoff & Auto \\
\hline Homology & Included \\
\hline Genes In Node & All \\
\hline Use FDR & False \\
\hline Hide Unemphasized & False \\
\hline p-value & 1 \\
\hline Minimum Overlap & $1 \%$ \\
\hline Minimum Genes & 1 \\
\hline Permutation Time Limit & 5 \\
\hline Max In Node & 4 \\
\hline Permutations & 0 \\
\hline Max Level & 40 \\
\hline
\end{tabular}

Table 2 Parameters used for both runs of the Geneweaver HiSIM graph 
bioRxiv preprint doi: https://doi.org/10.1101/2021.04.06.438717; this version posted April 15, 2021. The copyright holder for this preprint (which was not certified by peer review) is the author/funder, who has granted bioRxiv a license to display the preprint in perpetuity. It is made available under aCC-BY-NC-ND 4.0 International license.

\begin{tabular}{|l|l|l|}
\hline Num Genesets & Gene & Genesets \\
\hline 7 & HLA-B & $\begin{array}{l}\text { Behçet's GWAS [24], BD Gene2Mesh, Behçet's GWAS [23], } \\
\text { Behçet's GWAS [27], Malacards BD [32], Immune Genetics of } \\
\text { BD [8], Behçet's GWAS [34] }\end{array}$ \\
\hline 6 & IL-10 & $\begin{array}{l}\text { Intestinal Behçet's GWAS[24], Behçet's GWAS [34], BD } \\
\text { Gene2Mesh, Behçet's GWAS [25], Malacards BD [32], Im- } \\
\text { mune Genetics of BD [8] }\end{array}$ \\
\hline 5 & $\begin{array}{l}\text { BD Gene2Mesh, Behçet's GWAS [34], Malacards BD [32], } \\
\text { Immune Genetics of BD [8], Behçet's GWAS [25] }\end{array}$ \\
\hline 4 & HLA-A & $\begin{array}{l}\text { BD Gene2Mesh, Behçet's GWAS [23], Behçet's GWAS [34], } \\
\text { Immune Genetics of BD [8] }\end{array}$ \\
\hline 4 & $\begin{array}{l}\text { Immune Genetics of BD [8], BD Gene2Mesh, Behçet's GWAS } \\
\text { [28], Behçet's GWAS [26] }\end{array}$ \\
\hline 4 & $\begin{array}{l}\text { Intestinal Behçet's GWAS[24], Malacards BD [32], Behçet's } \\
\text { GWAS [26], Immune Genetics of BD [8] }\end{array}$ \\
\hline STAT4 & $\begin{array}{l}\text { BD Gene2Mesh, Behçet's GWAS [28], Immune Genetics of } \\
\text { BD [8], Behçet's GWAS [34] }\end{array}$ \\
\hline
\end{tabular}

Table 3 Abbreviated results from the BD HiSIM run. IL10 was identified in 7 genesets making it the most common gene amongst all tested genes. HLA-B was the next most common gene and was found in 6 genesets. IL23R was the third most common gene; it was found in 5 genesets. Finally, HLA-A, STAT4, MICA, and ERAP1 were all found in 4 genesets. 


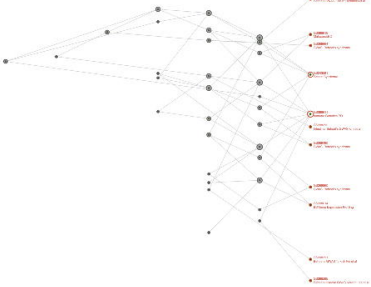









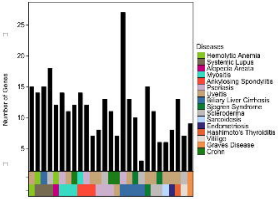




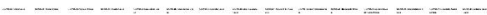

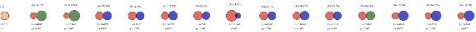

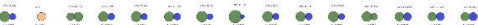

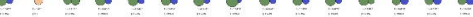

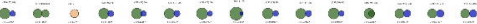

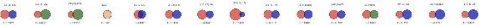

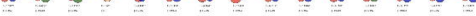

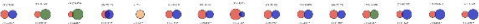

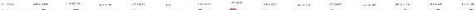

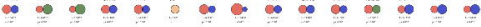

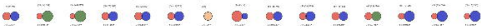

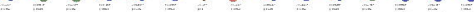

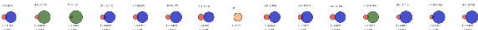

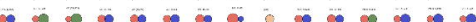

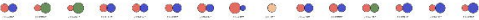

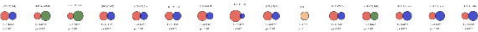

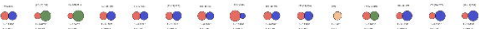

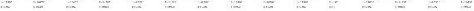

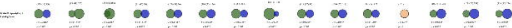

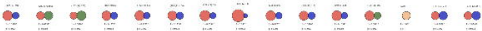

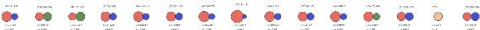

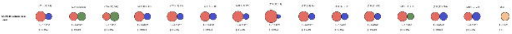
Zn

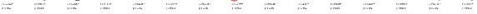

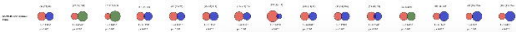




\section{9-toris Diener}

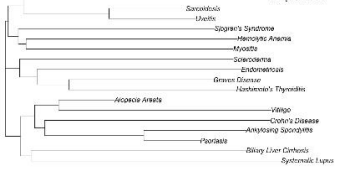

